\title{
A Review on Recent Advancement on Age-Related Hearing Loss: The Applications of Nanotechnology, Drug Pharmacology, and Biotechnology
}

\author{
Jacqueline Chester 1,2, Edan Johnston 1,2, Daniel Walker 1,2®, Melissa Jones ${ }^{1,2}$, Corina Mihaela Ionescu 1,2, \\ Susbin Raj Wagle ${ }^{1,2} \oplus$, Božica Kovacevic ${ }^{1,2} \oplus$, Daniel Brown ${ }^{1} \oplus$, Momir Mikov ${ }^{3}$, Armin Mooranian ${ }^{1,2, *}$ \\ and Hani Al-Salami ${ }^{1,2, *}$
}

check for updates

Citation: Chester, J.; Johnston, E.; Walker, D.; Jones, M.; Ionescu, C.M.; Wagle, S.R.; Kovacevic, B.; Brown, D.; Mikov, M.; Mooranian, A.; et al. A Review on Recent Advancement on Age-Related Hearing Loss: The Applications of Nanotechnology, Drug Pharmacology, and Biotechnology. Pharmaceutics 2021, 13, 1041. https://doi.org/10.3390/ pharmaceutics13071041

Academic Editor: Montse

Mitjans Arnal

Received: 4 June 2021

Accepted: 1 July 2021

Published: 8 July 2021

Publisher's Note: MDPI stays neutral with regard to jurisdictional claims in published maps and institutional affiliations.

Copyright: (c) 2021 by the authors. Licensee MDPI, Basel, Switzerland. This article is an open access article distributed under the terms and conditions of the Creative Commons Attribution (CC BY) license (https:/ / creativecommons.org/licenses/by/ $4.0 /)$.
1 The Biotechnology and Drug Development Research Laboratory, Curtin Medical School \& Curtin Health Innovation Research Institute, Curtin University, Perth, WA 6102, Australia; j.chester@graduate.curtin.edu.au (J.C.); edan.johnston@student.curtin.edu.au (E.J.); daniel.walker1@postgrad.curtin.edu.au (D.W.); melissa.a.jones@postgrad.curtin.edu.au (M.J.); c.ionescu@postgrad.curtin.edu.au (C.M.I.); susbinraj.wagle@postgrad.curtin.edu.au (S.R.W.); bozica.kovacevic@postgrad.curtin.edu.au (B.K.); daniel.brown2@curtin.edu.au (D.B.)

2 Hearing Therapeutics, Ear Science Institute Australia, Queen Elizabeth II Medical Centre, Perth, WA 6102, Australia

3 Department of Pharmacology, Toxicology and Clinical Pharmacology, Faculty of Medicine, University of Novi Sad, Hajduk Veljkova 3, 21000 Novi Sad, Serbia; MOMIR.MIKOV@mf.uns.ac.rs

* Correspondence: a.mooranian@curtin.edu.au (A.M.); hani.al-salami@curtin.edu.au (H.A.-S.)

\begin{abstract}
Aging is considered a contributing factor to many diseases such as cardiovascular disease, Alzheimer's disease, and hearing loss. Age-related hearing loss, also termed presbycusis, is one of the most common sensory impairments worldwide, affecting one in five people over 50 years of age, and this prevalence is growing annually. Associations have emerged between presbycusis and detrimental health outcomes, including social isolation and mental health. It remains largely untreatable apart from hearing aids, and with no globally established prevention strategies in the clinical setting. Hence, this review aims to explore the pathophysiology of presbycusis and potential therapies, based on a recent advancement in bile acid-based bio-nanotechnologies. A comprehensive online search was carried out using the following keywords: presbycusis, drugs, hearing loss, bile acids, nanotechnology, and more than 150 publications were considered directly relevant. Evidence of the multifaceted oxidative stress and chronic inflammation involvement in cellular damage and apoptosis that is associated with a loss of hair cells, damaged and inflamed stria vascularis, and neuronal signalling loss and apoptosis continues to emerge. New robust and effective therapies require drug delivery deeper into the various layers of the cochlea. Bile acid-based nanotechnology has gained wide interest in its permeation-enhancing ability and potential for numerous applications in treating presbycusis.
\end{abstract}

Keywords: antioxidant; age-related hearing loss; age; metformin; biguanides; bile acids

\section{Introduction}

Worldwide, hearing loss effects an estimated 1.57 billion people and is the third largest contributor of years lived with disability as of 2019 and this figure is predicted to increase annually [1]. Sensorineural hearing loss (SNHL) refers to the loss of hearing via maladies of the inner ear, most commonly caused by irreversible damage and the subsequent loss of cochlea hair cells and auditory neurons. A specific category of SNHL is age-related hearing loss (ARHL), more commonly termed presbycusis. The emergence of links between an excess of reactive oxygen species (ROS) and SNHL-associated damage has spurred preventative and restorative pharmacological management research for SNHL and specifically ARHL. Even with this newfound focus into antioxidant therapy for ARHL, 
there is still a current unmet need in the pharmacological prevention, management, and reversal of hearing loss [2].

Bile acids have previously been utilised to improve pharmacokinetics of drugs with poor delivery profiles [3]. In addition to examining the recent developments in ARHL pathophysiology and potential drug therapies, this review will explore the benefits of bile acid incorporation into drug delivery models in the context of ARHL.

\section{Methodology}

A literature search was conducted using Endnote X9 online search, PubMed and Google Scholar incorporating the following key words: "presbycusis", "age-related hearing loss", "oxidative stress", "aging", "antioxidant", "biotechnology", "bile acids, "nanotechnology", and "bile acids". Studies from 2017 to 2020 in the English language were considered for potential use. Abstracts were read for studies involved and those using a combination of the previously mentioned terms were considered and read in full. All studies sourced externally from these search criteria were found via the citation list of established references.

\section{Function of the Ear}

The human ear is comprised of the following three sections: the outer ear, middle ear, and inner ear. The external and visible structure of the ear is the auricle, which is the most lateral part of the outer ear and has acoustically engineered anatomy functioning to improve sound localisation and facilitate the amplification and subsequent channelling of sound. This structure funnels into the external auditory canal and the tympanic membrane, terminating at the tympanic membrane. Filled with air, the middle ear compartment houses the Eustachian tube, muscles of the middle ear, structures of innervation, and the ossicles. The Eustachian tube equalises the pressure within the middle ear to the ambient pressure of the outer ear via its connective opening in the nasopharynx, allowing for the optimal functionality of the tympanic membrane. The ossicles consist of three interconnected bones known as the malleus (fixed to the tympanic membrane), the stapes (fixed to the oval window to the inner ear), and the incus (connecting the malleus and stapes) [4]. Attached to the stapes is the stapedius muscle and attached to the malleus is the tensor tympani muscle, which are innervated by the facial and trigeminal cranial nerves, respectively. In response to acoustic trauma below a frequency of $2 \mathrm{kHz}$, these muscles contract, reducing ossicular auditory amplification via the stabilisation of the bony chain [5]. This apparatus delivers and amplifies vibrational movement from the external ear, through the middle ear, and to the cochlea [4].

The inner ear encloses the cochlea, vestibular apparatus, and the semi-circular canals [4]. The cochlea is spiral-like in shape and compartmentalised into the following three parallel membranous chambers: the endolymph-containing scala media and the scala vestibuli and the scala tympani, both containing perilymph and travelling above and below the scala media, respectively [6]. Perilymph is high in $\mathrm{Na}^{+}$concentration and low in $\mathrm{K}^{+}$ concentration with a net ionic effect of $-80 \mathrm{mV}$ [7]. Conversely, the endolymph within the scala media has a concentration of high $\mathrm{K}^{+}$and low $\mathrm{Na}^{+}$that is primarily maintained by the $\mathrm{Na}^{+}-\mathrm{K}^{+}$-ATPase pumps on the apical border of the stria vascularis epithelial cells forming the lateral boundary of the scala media. The scala media is bordered by the Reissner's membrane and the basilar membrane, segregating it from the scala vestibuli and the scala tympani, respectively [8]. Within the centre of the cochlea structure is the modiolus containing the spiral ganglions, which project and combine to form the cochlear nerve referring action potentials from the organ of Corti sensory cells to the brain for sound recognition and processing [9].

The organ of Corti is considered the functional unit of auditory processing within the cochlea for, and is made up of, hair cells and their supporting cells arranged in a highly organised asymmetrical mosaic pattern along the span of the basilar membrane. Hair cells are considered the sensory cells of the cochlea, categorised by their location and function. 
Outer hair cells (OHCs) are in a triad row along the basilar membrane, and they function to amplify specific frequencies of vibrational movement. Inner hair cells (IHCs) travel in a singular row along the basilar membrane and are responsible for the transduction of vibrational movement from the cochlear to the auditory neurons. The supporting cells are organised in very precise patterns within the organ of Corti, including, but not limited to, pillar cells, Hensen's cells, phalangeal cells, and Dieter's cells [6].

When sound waves enter the external ear and are transferred to the oval window via the ossicular chain, the scala vestibuli is mobilised. This movement travels the length of the cochlea and returns to the base of the scala tympani, displacing the round window. This induces a wave of movement along the basilar membrane to be absorbed and detected by the correlating $\mathrm{OHCs}$. Stereocilia atop $\mathrm{OHCs}$ are connected to adjacent stereocilia $\mathrm{K}^{+}$ ion channel gates via tip-links. The shear stress of the wave motion pulls the tip-links, opening the $\mathrm{K}^{+}$ion channels allowing cellular influx of endolymph $\mathrm{K}^{+}$, depolarising the OHCs [10]. A depolarised OHC rhythmically contracts, actively amplifying the mechanical stimulation of an IHC, which depolarises via the same mechanism. The depolarisation of an IHC triggers the influx of $\mathrm{Ca}^{2+}$, triggering the release of glutamate into the synapse preceding the afferent neuron connection of a spiral ganglion. This signal is then projected by the spiral ganglion to the brain via the vestibulocochlear nerve $[9,11]$.

\section{Age-Related Hearing Loss}

Age-related hearing loss is a disease that is currently irreversible, resulting from the cumulative effects of long-term damage to structures of the inner ear and associated neurons. Currently, ARHL is the largest contributing morbidity towards years lived with disability for populations over 70 years of age [1]. It was estimated that, in 2019, the global economic cost of hearing loss was estimated to be over $\$ 981$ billion (2019 purchasing power parity adjusted international dollars) and $30.7 \%$ of that cost was attributed to health care in adult hearing loss [12]. The presentation of ARHL begins typically with difficulty discerning speech, particularly in noisy environments, then progresses to the loss of hearing sensitivity, a reduced ability to localise sound origin, and a decrease in central auditory processing $[13,14]$. The risk of cognitive decline, depression, and social isolation is increased for those with ARHL, and over the past decade, ARHL has also been associated with dementia development [14-20]. Treatment of symptoms is limited to hearing-aids and, in more severe cases, cochlear implants; but currently, no pharmacological intervention exists. The increasing health and economic burdens associated with ARHL demonstrates the need for a suitable therapeutic intervention $[1,12]$.

\subsection{Pathophysiology of Age-Related Hearing Loss}

The definition of aging is controversial and highly dependent on the context in which it is approached, whether it is physiological, molecular, psychological, or functional. In summary, it is a time-dependent process denoting the cumulative loss of function and increase in vulnerability [21]. In 1956, the free radical theory of aging was established by Denham Harman, attributing aging adjacent functional loss as a consequence of structural damage to macromolecules via oxidative stress [22]. This theory was updated in 2014 to the "free radical theory of frailty" to highlight the relationship of oxidative stress with the state of frailty, as opposed to its previously accepted relationship with chronological age [23]. The irreversible loss of hair cells and spiral ganglion cells, and degeneration of the stria vascularis is believed to be the cause of ARHL [14]. The exact mechanisms behind damage to these areas is still being explored, but over time more evidence has come to light supporting the theory that oxidative stress and inflammation incur the deleterious effects leading to this damage $[24,25]$.

\subsubsection{Oxidative Stress}

Oxidative stress is the unequillibrium in pro-oxidant production against antioxidant production and buffering capacity in favour of pro-oxidants. Pro-oxidant compounds 
are primarily reactive oxygen species (ROS) capable of exchanging one of their free valence electrons with oxygen in the body incurring damage of various macromolecules, but predominantly, nucleic acids, lipids, and proteins [26,27]. Several factors increase ROS production in ARHL, such as noise-exposure, ototoxic drugs, and age-related devascularisation and blood flow reduction [14,28,29]. In addition, antioxidant activity is concurrently reduced with age, exacerbating the ROS-antioxidant imbalance [2]. Mitochondria produce the majority of ROS as by-products of cellular respiration, specifically from the Krebs's cycle and oxidative phosphorylation process [29]. Excessive ROS production adversely affects mitochondrial DNA (mtDNA), incurring deletions and mutations within the genome. Alterations in mtDNA leads to extreme dysregulation in oxidative phosphorylation, further increasing ROS production and inducing cellular damage capable of initiating apoptotic pathways [30,31].

Numerous studies have clarified the involvement of the Kelch-like ECH-associated protein 1-NF-E2-related factor 2 (NRF2-KEAP1). Under normal functioning conditions, NRF2 is inhibited by KEAP-1, but in conditions of increased ROS, KEAP-1 is modified, liberating NRF2 to initiate robust antioxidant and anti-inflammatory signalling. NRF2 is translocated for interaction with the antioxidant response element (ARE), inducing gene expression of antioxidants including superoxide dismutase (SOD), $\mathrm{NAD}(\mathrm{P}) \mathrm{H}$, quinone oxioreductase-1 (NQO1), and heme oxygenase-1 (HO-1).

NRF2 is downregulated with progression of age and, in these circumstances or during states of chronic excess ROS production, NRF2-regulated cytoprotection and redox stability is hindered [32,33]. Several functions of NRF2 include the regulation of mitochondrial homeostasis, the regulation of antioxidant enzyme expression, prevention of cellular apoptosis, DNA repair, and transcriptional regulation [34-36]. An age-related reduction in NRF2 activity affects numerous other biochemical processes contributing to an increased ROS and subsequent ARHL [37].

In addition to mitochondria ROS, $\mathrm{NAD}(\mathrm{P}) \mathrm{H}$ oxidases (NOX) account for a moderate degree of ROS production. There are seven types of NOX enzymes in mammals in various locations in the body and with differing functions. One of their functions is shared between all NOX: oxidising $\mathrm{O}_{2}$ into $\mathrm{O}_{2}{ }^{-}$, which, either spontaneously or by SOD, can be converted into $\mathrm{H}_{2} \mathrm{O}_{2}$. Although the collective functions of NOX enzymes have not been entirely uncovered, it has been shown that this family has essential roles in host defence, the proliferation and differentiation of cells, cellular signalling, and apoptosis metabolism [38]. Similar to the mitochondrial redox regulation, NOX overactivation leads to oxidative stress and its associated cytotoxic damage. NOX3 is almost explicitly expressed within the inner ear, but its effects have been documented in emphysema development and insulin resistance in mice $[38,39]$. The p22 ${ }^{\text {phox }}$ subunit is responsible for the activation of NOX $1-4$. The reduction in NOX activity presented in p22 ${ }^{\text {phox }}$ knockout mice attenuated hearing loss in addition to the preservation of cochlear morphology when compared to control wild-type mice. It has been posed that the targeting of NOX activity within the inner ear could be a potential pathway for therapeutic intervention of ARHL [40].

\subsubsection{Inflammation}

Aging is accompanied by chronic inflammation, termed "inflammaging", and dysregulation of the immune system attributable to oxidative stress, apoptosis activation, and mitochondrial dysfunction [41,42]. Chronic inflammation, consisting of persistent low-grade inflammation in tissues, is heavily linked to aging and an increased risk of cardiovascular diseases, diabetes, cancer, and senile dementia [41,43]. In addition to the persistent activation of the innate immune system, the chronic elevation of interleukin-6 (IL-6), Interleukin-1 beta (IL-1 $\beta$ ), Interleukin-2 (IL-2) and tumour necrosis factor-alpha $(\mathrm{TNF}-\alpha)$ are notable cytokines associated with auditory loss [24,42,44,45]. Chronic inflammation and ROS have been linked via the ROS activation of nuclear factor-kappa B $(\mathrm{NF}-\mathrm{kB})$. Long-term oxidative stress instigates chronic inflammation and proinflammatory cytokine production, which inadvertently increases ROS production. Another by-product 
of ROS is proinflammatory cytokine promotion, which in turn increases inflammation. This further increases ROS production and initiates a positive feedback effect that causes chronic damage $[43,46]$. The targeted inhibition of transcription factor NF- $\mathrm{kB}$ has been presented as a potential mediator of age-related inflammation [44,47]. Notably, NF- $\kappa$ B can be activated by ligand binding of TNF- $\alpha$ to the TNF- $\alpha$ receptor 1 (TNFR1) death ligand involved in the extrinsic apoptosis pathway. The result of this is proinflammatory cytokine synthesis ultimately increasing TNF- $\alpha$, creating a positive feedback loop [48]. TNF- $\alpha$ has also been implicated in ARHL in context of both inflammaging and inner hair cell synaptic degeneration $[42,49]$ The responsibilities of NF- $\mathrm{KB}$ are numerous and varied, functioning to regulate inflammatory responses, cell regeneration and proliferation, apoptotic signalling, and anti-apoptotic signalling. The states of oxidative stress that are triggered by or involve NF- $\mathrm{BB}$ can be both antiapoptotic or proapoptotic; thus, regulation requires contextually relevant understanding and targeting [50].

\subsubsection{Cellular Apoptosis}

Apoptosis is a highly regulated process to induce cell death and has been shown as a major contributor to ARHL through hair cell death [51]. This process is regulated by genes and enzymes via the endoplasmic reticulum, intrinsic, and extrinsic pathways. Apoptosis pathways involve cysteine-aspartic protease (caspase) enzymes and is primarily regulated by Bcl-2 family proteins. In caspase-mediated apoptosis, the intrinsic and extrinsic pathways have unique initiator phases; but both share similar pathways in execution phase resulting in cell death via activation of caspase 3 and 7. The extrinsic pathway initiates via the binding of a death ligand to its concomitant death receptor, which belongs to the TNF superfamily. This stimulates a cascade of events leading to the death-inducing signalling complex (DISC) consequently activating caspase 8 . The activation of caspase 8 stimulates the caspase 3 mediated execution phase. The intrinsic pathway is initiated via intracellular factors such as DNA damage, cytotoxicity, and ROS, which are sensed by BH3-only proteins. Bcl-2 family proteins, Bax and Bak, are stimulated by BH3-only proteins to create a mitochondrial outer membrane pore (MOMP), allowing the release of cytochrome $\mathrm{C}$ into the cytoplasm. The translocation of Bax and Bak are inhibited by antiapoptotic proteins of the Bcl-2 family including Bcl-2, preventing apoptosis. The cytochrome $\mathrm{C}$ binds to Apaf-1, activating caspase 9-the initiator of the execution phase. The executioner phase in these pathways involves the activation of caspase 3,6 and 7, which function to destroy nuclear proteins, induce DNA and chromatin degradation, alter cytoskeleton arrangement, and disrupt cell division and communication. Ultimately, fragments of the cell are recognised and phagocytosed by epithelial cells and macrophages [52,53]. Both rat and mice models have been established for AHRL via D-galactose injection inducing $\mathrm{H}_{2} \mathrm{O}_{2}$-related oxidative stress-associated damage predominantly through mtDNA deletion and repeats, NOX overexpression, and uncoupling protein-2 (UCP2) promotion [54-56]. The expression of NOX3 in the stria vascularis, spiral ganglion, and organ of Corti, and the detection of cleaved caspase 3 cells was significantly increased in D-gal rats in comparison to the control rat model counterparts [57]. Previous research using D-Gal rats has demonstrated a significant increase in the NOX2 expression in the ventral cochlear nucleus and the NOX3 expression within the inner ear structures. These studies also highlighted mitochondrial morphological disruption and increased the cleaved caspase in the inner ear, inferring the involvement of the mitochondrial intrinsic pathway of apoptosis [54,57]. Research suggests that ROS act as p53 up-regulators, inducing continuous Bak activation, eventually leading to apoptosis in AHRL [58]. Similarly, in the C57BL/6J ARHL mouse model, Bak gene deletion prevented the apoptosis of hair cell and spiral ganglion neuronal cells [59].

\subsubsection{Autophagic Cell Protection}

Autophagy is a regulatory mechanism triggered by the stimuli of environmental stress within a cell. The essential process denotes the containment, engulfment, and subsequent breakdown of degraded abnormal or damaged intracellular structures via the lysosome into 
more basic units (e.g., amino acids, nucleotides, fatty acids, etc.) for reuse [60]. Autophagy is regulated by rapamycin kinase mammalian target (mTOR). The inhibition of mTOR occurs via the $\mathrm{p} 53$ and adenosine 5-'monophosphate activated protein kinase (AMPK) signalling pathway, increasing autophagy. The opposite occurs via the up-regulation of mTOR via MAPK and Akt pathway signalling, attenuating autophagy. During persistent oxidative stress, NRF2 reduces AMPK expression, suppressing extended autophagy and, thereby, preventing excessive destruction of cellular contents over time [61]. A reduction in NRF2 expression has been identified in ARHL, diminishing this protective mechanism and allowing a build-up of damaged and abnormal intercellular contents [62]. Protein synthesis occurs within the endoplasmic reticulum (ER). The ER evaluates synthesised proteins for abnormal assembly, subsequently destroying and recycling them when identified via either autophagy-lysosome or ubiquinone-proteasome systems [63]. Approximately, one-third of the proteins produced undergo this [60]. This process, termed the unfolded protein response (UPR), is a stress response, which may trigger apoptosis via caspase 12 release, cJun N-terminal kinases (JNK) expression, or upstream C/EBP homologous protein (CHOP) gene pathway activation when overwhelmed. In addition to this, chronic UPR activation and ER stress eventually inhibits autophagy, increasing the degree of misfolded and damaged proteins. Finally, chronic ER stress may trigger ROS production itself via NF- $k B$ activation $[53,64]$.

\subsubsection{Recent Findings}

The linkage between diabetes mellitus (DM), dementia, and hearing loss is controversial; however, in the past decade, numerous studies have shown relationships between these pathologies, supporting the link [16,65-70]. Diabetes mellitus is characterised by chronic insulin insensitivity or deficiency, resulting in hyperglycemia and the degeneration of vasculature [71]. Dementia is also a chronic disorder of degeneration, presenting as cognitive decline and behavioural abnormalities. The underlying pathology includes, but is not limited to, neuronal loss in both the hippocampal and temporal regions, neurofibrillary tangles, vascular degeneration, and amyloid-beta plaque formation [70]. Metabolic dysregulation underlies all three diseases and the impact of this dysregulation increases with age, elucidating the categorization of these diseases to include geriatric syndrome [72]. The SAMP8 mouse model commonly used for ARHL is also used in contexts of diabetes and dementia due to the ubiquitous involvement of cellular senescence in all three pathologies [73-75]. Though DM and dementia are not the focus of this review, these developments show the potential for a greater understanding of ARHL, but also highlight potential future therapies with multi-targeted functional design.

\section{Antioxidants}

Antioxidants are molecules (either endogenous or exogenous) that serve to eliminate ROS or reduce the damage of ROS. The instigation of antioxidant release occurs in response to the presence of ROS within proximation to an extracellular matrix, cells, and tissues. The natural antioxidant defence of the body is via endogenous antioxidants, which, dependent on their function, are categorised as either enzymatic or non-enzymatic [76]. Both categories of endogenous antioxidants operate against differing ROS and within differing compartments of the cells, allowing the complementary mechanism of protection [43]. Glutathione reductase (GR), catalase (CAT), glutathione peroxidase (GPx), and SOD are enzymatic firstline defenders against ROS. Superoxide anions are catalysed into hydrogen peroxide via SOD, which is subsequently neutralised into a single water and oxygen molecule by CAT, GPx, or GR. Exogenous antioxidants are commonly found in diet and work symbiotically with endogenous antioxidants in restoration of cellular homeostasis [76].

Oxidative stress reduction requires a decrease in ROS or an increase in antioxidant activity. There are the following three mechanisms by which this can be achieved: the upregulation of endogenous antioxidants, introduction of exogenous antioxidants, and ROS-scavenger system promotion [77]. When addressing hearing loss prevention and 
management using antioxidants, it is imperative to be addressing multiple aspects of the highly multifaceted pathology. Several antioxidants have shown efficacy as a therapeutic intervention option in both noise-induced hearing loss and ototoxicity prevention but have not demonstrated similar benefits in ARHL. The pathogenesis of ARHL is still being elucidated; in addition, a practical and reliable delivery mechanism for therapeutic compounds to the inner ear is still required before any effective treatment can be pursued.

\section{Potential Antioxidants for Use in ARHL Treatment}

Metformin is a hydrophilic, positively charged biguanide compound commonly used to treat type $2 \mathrm{DM}$ as a sensitizer of insulin receptors and an antihyperglycemic agent. Its mechanism involves the stimulation of adenosine monophosphate-activated protein kinase (AMPK/ERK1/2), and through this mechanism has shown effects in anti-inflammatory, antiangiogenic, proapoptotic, and antioxidant contexts [78,79]. Metformin has shown to decrease ROS in long-term accumulation either via ROS scavenging or prevention of ROS production. In addition, metformin modulates inflammation and cellular degeneration and dysfunction associated with aging via NF- $\kappa$ B regulation [47]. Metformin was explored in the context of various aspects of hearing loss in D-galactose rats. Antioxidant activity (SOD, CAT and GSH) reduction increased in D-gal rats of 3 months, 9 months, and 15 months, respectively, when compared to age-matched counterparts in the control group. In the third group consisting of D-gal rats receiving metformin, the reduction in antioxidant activity seen in only D-gal group was attenuated to a significant degree. In addition to this, metformin abated mtDNA common deletions in both in vivo and in vitro groups, downregulated p53 expression and caspase 3 expression, prevented cellular apoptosis, decreased neurodegeneration associated with age, and finally, regulated UPR activity [80].

Probucol is commonly used for its cholesterol-lowering capabilities, but it has also shown antioxidant and anti-inflammatory benefits. Its therapeutic antioxidant qualities have been noted in a diverse range of pathological contexts but are yet to be explored in the context of ARHL [81-83]. For example, probucol has been found to suppress ROS upregulated $\mathrm{p} 66^{\mathrm{Shc}}$ adaptor protein expression via NAD-dependent deacetylase sirtuin1 (SIRT1) upregulation and also via the decrease and increase in upstream caspase 3 mediators, p-JNK, and activated extracellular signal-regulated kinases (p-ERK1/2), respectively $[81,84]$. The pathways activated by $\mathrm{p} 66^{\text {Shc }}$ promotion can increase ROS production, reduce antioxidant production, and trigger cytochrome C-induced apoptosis [85]. In addition, probucol prevents apoptosis via Bax and p53 downregulation, and Bcl-2 upregulation $[84,86]$. Though the exact mechanism is not known, probucol shows antioxidative properties via the inhibition of NOX2 expression, which has been identified as a potential therapeutic target in ARHL [82]. The promotion of NRF2 activity has been noted in several studies in addition to its down-stream processes $[83,87,88]$. Probucol promotes recruitment of potent antioxidants NQO1, HO- 1 , and SOD $[83,88,89]$. The promotion of NQO1 exerts antioxidant effects by converting quinone to hydroquinone, effectively preventing quinone conversion into semiquinones via cytochrome P450 reductase. Semiquinones are subject to further a reaction with $\mathrm{O}_{2}$ due to its unstable nature, producing an ROS [36]. HO-1, on the other hand, is capable of oxidising prooxidant heme into carbon monoxide and, indirectly, bilirubin, which both possess cellular protective functions [90]. Given probucol's up-regulation of NRF2 expression, it presents a viable option for potential benefits in ARHL prevention and management [33]. Therapeutic applications of probucol have been previously shown to reduce proinflammatory cytokines TNF- $\alpha$, IL-1 $\beta$, IL-6, IFN- $\gamma$, and increase the anti-inflammatory cytokine IL-10 [83,91-93]. Probucol provides extremely multifaceted mechanisms of assistance in ARHL, as summarised in Figure 1, but despite its effectiveness, probucol requires a well-developed method of drug delivery. Probucol is both low in bioavailability and highly lipophilic; and consequently, previous use of probucol has required increased doses to reach a therapeutic effect. Subsequently, heart arrythmias have been reported as a side effect due to the high inter-individual drug specificity [94]. 


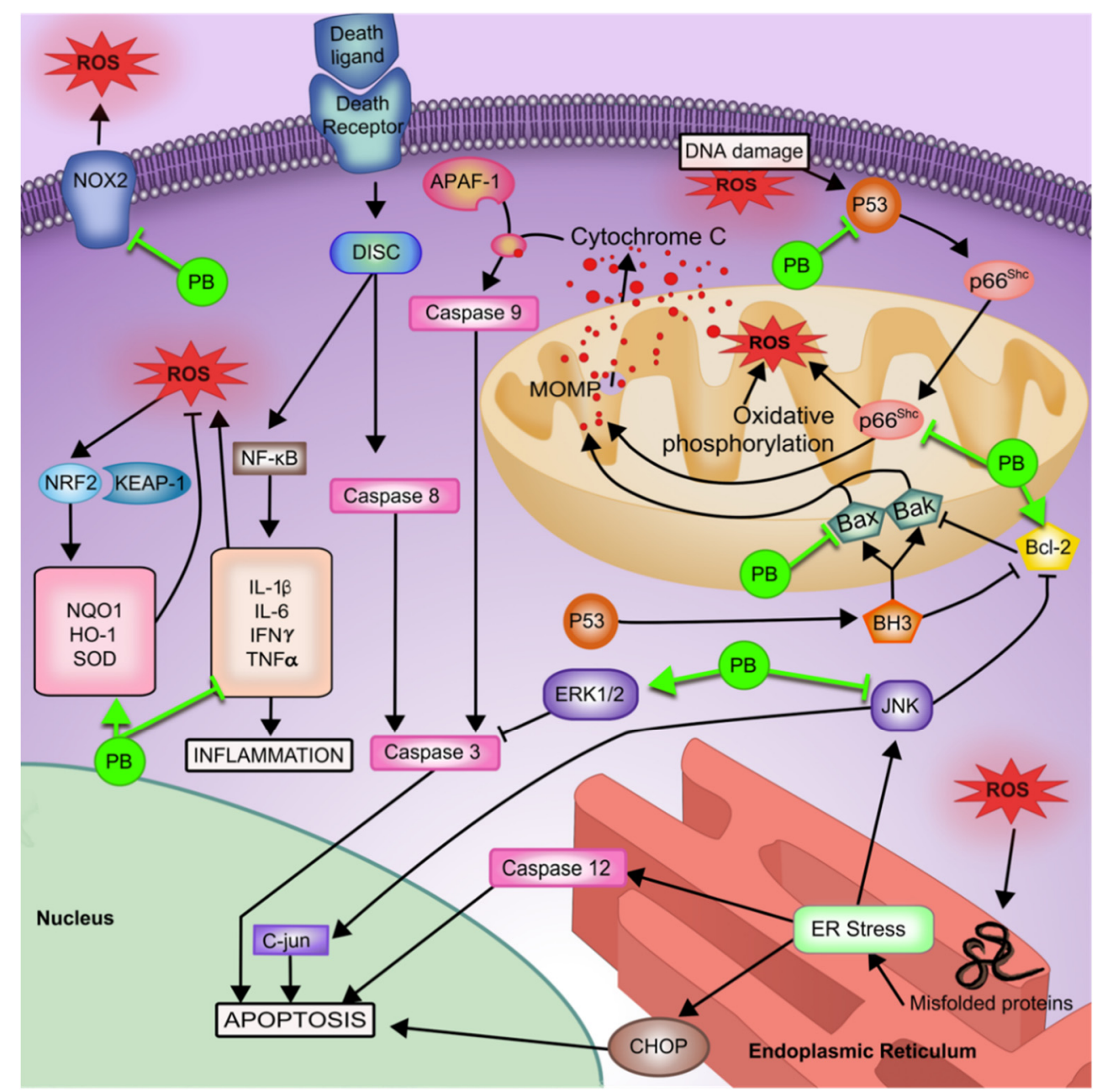

Figure 1. Schematic diagram of various cellular therapeutic effects of probucol in context of oxidative stress induced pathologies underlying ARHL. Abbreviations: PB, probucol; DNA, deoxyribonucleic acid; ROS, reactive oxygen species; NRF2, NF-E2-related factor 2; KEAP-1, Kelch-like ECH-associated protein 1; NQO1, NAD(P)H:quinone oxioreductase-1; HO-1, heme oxygenase-1; SOD, superoxide dismutase; DISC, death inducing signalling complex; IL-6, Interleukin-6; IL-1 $\beta$, interleukin-1 beta; IFN $\gamma$, interferon-gamma; TNF $\alpha$, tumour necrosis factor-alpha; NF- $\mathrm{B}$, nuclear factor-kappa B; BH3, $\mathrm{BH} 3$ only protein; MOMP, mitochondrial outer membrane pore; JNK, c-Jun N-terminal; ERK1/2, extracellular signal-related kinases 1 and 2; CHOP, C/EBP homologous protein; ER, endoplasmic reticulum.

These outlined antioxidants show potential as a therapeutic option in the antioxidantbased prevention of ARHL, either used alone or in combination. Regardless of the effectiveness that these compounds may provide, they need to be physically deliverable to the intended site, that is, the inner ear. This poses the following several challenges: the pharmacokinetics of the drug, and the inner ear locational difficulty. Microencapsulation and nanotechnology in drug delivery are known for their ability to improve delivery outcomes for unfavourable drug delivery profiles of pharmaceuticals, making them potential options for improving the delivery outcomes of metformin and probucol [95,96].

\section{The Existing Barriers in Effective Treatment of Age-Related Hearing Loss}

Held in the petrous bone-an extremely dense bone [97] — the inner ear provides a challenge when devising a targeted drug delivery method. Currently, a systemic administration of steroid through oral or intravenous routes is established as a treatment method for sudden sensorineural hearing loss and Meniere's disease [98]. Systemic applications are 
problematic due to the omnipresent binding sites between both target and off-target cells. A consequence of this is the unfavourable off-target binding of the therapeutic agent and the subsequent adverse effects within the body [99]. Another concern with this delivery method is the sub-therapeutic levels of the drug reaching the target site due to the bloodperilymph barrier separating the inner ear from systemic circulation [99,100]. Larger doses of the treating drug are required for effective therapeutic dosage, further increasing the risk of systemic side effects [101]. Local delivery to the inner ear is being explored as a promising route of drug delivery, thereby, eliminating the risks associated with systemic drug exposure and decreasing the required dose for therapeutic effect [100].

The round window membrane (RWM) has traditionally been understood as the main route of transport separating the middle and inner ear compartments. It consists of an inner and outer epithelial layer with a middle layer of connective tissue, combining to be an average thickness of $70 \mu \mathrm{m}$. Contained within the connective tissue layer are elastic fibres, collagen, and fibroblasts in addition to lymph and blood vessels [102]. The permeability of the RWM depends on the size, surface charge, hydrophilicity, RWM thickness, and total contact time with the RWM [103-111]. Clearance of the middle ear via the Eustachian tube is another concept to consider when designing an inner ear drug delivery system. This consistent elimination of the contents of the middle ear can result in the necessity for repeated injections to achieve therapeutic levels, prompting research efforts into controlled drug release and the retainment of drug carriers in the middle ear [95,112-115].

\section{Local Drug Delivery of Antioxidants to Inner Ear}

Research on and the application of drug delivery systems to the inner ear is shifting to local delivery systems aiming to avoid the blood-perilymph barrier. In addition, this form of delivery allows drugs either low in bioavailability and/or known to induce systemic side effects, such as metformin and probucol, to be delivered more effectively and safely. As previously mentioned, probucol has historically caused cardiac arrythmias in patients due to its inter-individual variability in oral bioavailability. The combination of both the low bioavailability of metformin and the challenge of crossing the blood-perilymph barrier makes local delivery a more appealing delivery system moving forward in inner ear delivery $[79,94,100]$. Local drug delivery can be achieved via transtympanic, intracochlear, or intratympanic delivery (ITD) [98]. Transtympanic delivery involves application of the pharmaceutical to the tympanic membrane for permeation into the middle ear. The noninvasive nature of this application makes it favourable for patient comfort, but this is at the expense of the bioavailability of the drug at the target site. Intracochlear delivery to the inner ear involves the delivery of drugs directly into the cochlea through invasive surgery. Bioavailability is a major benefit to this technique, but it requires a procedure with specialised staff in a hospital. The risks of acoustic trauma are increased via disruption of the delicate fluid balance within the cochlea and the subsequent sheer stress of hair cell, toxicity due to high drug concentration, or via introduction of a pathogen into the inner ear. The methodology of ITD involves the delivery of the drug directly into the middle ear for diffusion into the inner ear, bypassing the tympanic membrane and reducing the acoustic trauma risks associated with intracochlear delivery. The success of ITD delivery depends heavily on transport across the RWM [95].

The thickness of the RWM is variable between individuals to some degree but is significantly increased in those with otitis media, thus decreasing its permeability [103-105]. With regard to size, smaller particles show greater permeability to the RWM than larger particles in a study comparing three nanocarriers of varying size. The largest nanocarrier $(240 \mathrm{~nm})$ demonstrated the lowest permeability and the smallest nanocarrier $(90 \mathrm{~nm})$ demonstrated the highest permeability [106]). Previous studies have shown an increase in RWM permeability resulting from positively charged molecules [107-109]. A study by Liu et al. analysed glycerol monooleate-based nanoparticles of varied charges and their transport characteristics regarding L929 cells, the RWM, and general cochlear distribution. It was concluded that the nanoparticles modified to have positive surface charge 
increased the permeability of the RWM and had an increased uptake by the L929 cells in addition to a greater overall cochlear biodistribution of the drug [108]. Comparatively, the RWM has shown higher affinity for the permeation of hydrophobic drugs compared to hydrophilic drugs [110]. The influence of change in concentration was explored when comparing a 190 mOsm and 620 mOsm trimethylphenylammonium (TMPA) in artificial perilymph solution. Permeability was increased by a factor of 2-3 for the higher drug concentration [111]. This behaviour has also been presented in Poly (lactic-co-glycolic acid) (PLGA) nanoparticles [116]. An increased contact duration of a solution with the RWM subsequently increases its permeability, as shown with PLGA nanoparticles [116] and TMPA solution [111].

In consideration to the barriers presented by diffusion across the RWM and Eustachian tube clearance rates, devices and modifications have been formulated to mitigate these challenges, improving ITD delivery [95,98,117-119]. Increasing the viscosity or mucosal adherence properties of an applied drug reduces Eustachian tube clearance, as seen in hydrogels [120-122]. Gelatinous sponges can be surgically placed within the middle ear for sustained drug release; [123-125] and finally, nanoparticle delivery systems are highly modifiable delivery systems allowing tailored approached to the improvement of RWM permeability $[95,126,127]$. Combinations of these methods are also explored, such as nanoparticle delivery in conjunction with hydrogels, gelatinous sponges or foams, as illustrated in Figure $2[121,128]$.

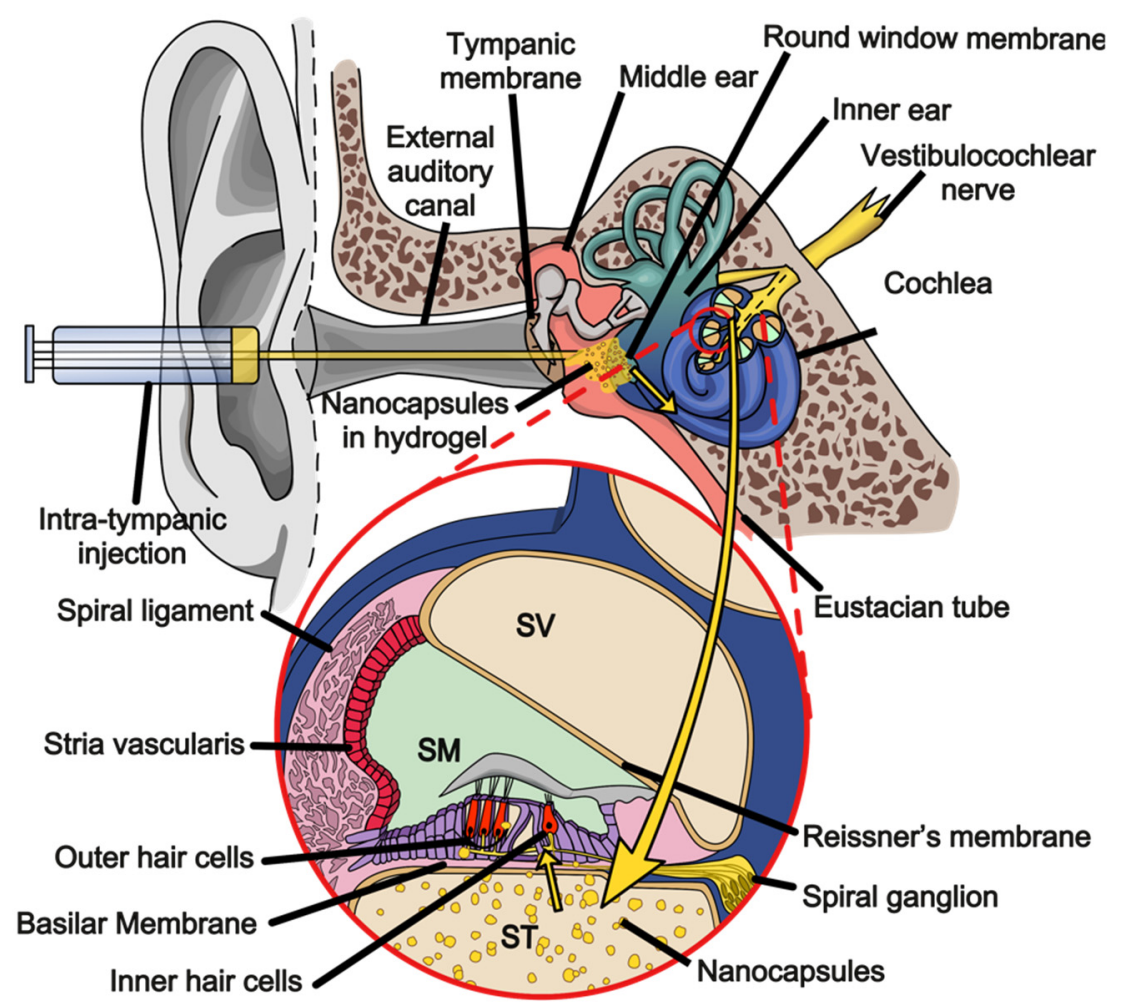

Figure 2. Illustration denoting intratympanic drug delivery of hydrogel nanocapsules into the cochlea. Injection bypasses transtympanic membrane into middle ear cavity and deposits drug in contact with round window membrane. ( $\mathrm{SV}=$ Scala vestibuli, $\mathrm{SM}=$ Scala media, $\mathrm{ST}=$ Scala tympani).

\section{Nano and Micro Drug Carriers}

Both microcapsules and nanoparticles are characterised by their size [129-132]. Their physiochemical characteristics and properties, such as shape, surface composition, excipients, and surface charge, are highly customizable, allowing for alleviation of unfavourable drug properties such as poor solubility, ineffective diffusion, degradation, and reduced half-life $[126,133,134]$. For a nanocarrier to be suitable for ITD, the following requirements 
need to be met: it must be able to load a sufficient amount of drug, resistant to clearance via Eustachian tube, transportable across the RWM, protective of delicate drugs, and able to maintain a prolonged RWM contact $[95,126]$. When designing a nanocarrier delivery system, the excipients and method of formulation for the carrier determine the physiochemical characteristics of the finalised capsule [126,135-138]. Several reviews have summarised the benefits of nanocarriers in applications to inner ear delivery, highlighting improvements in biodistributions and availability, RWM transportability, otoprotective effects, and the reduction in the targeted effect in the outer hair cells and stria vascularis $[95,113,139]$. The prospect of microencapsulation for inner ear drug delivery has not yet been explored, but due to its larger size, would not seem to be a viable option for RWM transport. However, microcapsules still maintain potential for ITD through sustained release if they are immobilised whilst in contact with the RWM for an extended duration of time [112,114]. Nanoencapsulation and microencapsulation of low-bioavailable drugs is a favourable method for improving bioavailability and transport characteristics, especially when using bile acids as an excipient in the encapsulation [135].

\section{Bile Acids}

Primary bile acids are endogenous molecules formed in the liver via several enzymatic alterations of the precursor, cholesterol $[140,141]$. The subsequent conjugation with taurine or glycine forms bile salts that possess reduced membranolytic and cytotoxic properties than their primary bile acid counterparts. These conjugates are stored within the gallbladder for postprandial release into the lumen of the small intestine. The bile salts released into the lumen aid in digestion and the subsequent absorption of lipophilic molecules via mixed micelle formation [142]. Within the large intestine (ileum and colon), unused bile salts are deconjugated by local microbiota and enzymatic action into secondary bile acids for reabsorption. The reabsorption of bile acids occurs at $95 \%$ efficacy, transporting bile acids back to the liver in a process called enterohepatic circulation. This process allows a consistent bile acid pool to be maintained for lipid digestion, without the requirement for increased production and higher, toxic levels of bile acids. In addition to digestive functions, bile acids have shown roles in endocrine signalling, the prevention of gall and kidney stone production, microbiota maintenance, and both local and immune functions [143]. In the recent literature, bile acids have shown, in addition to exerting therapeutic effect themselves, remarkable benefits for improving nanoencapsulation and microencapsulation in drug delivery outcomes $[3,144]$. The structure of bile acids consists of both hydrophobic and hydrophilic structural components. This results in bile acids possessing amphipathic characteristics that facilitate permeation enhancing effects across membranes due to detergent-like action. This enables the solubilisation of membranes and the improved permeability of lipophilic molecules possessing low bioavailability and high interindividual variation in pharmacokinetics, such as probucol [145]. The safety of bile acids when incorporated as an excipient in drug delivery has previously been questioned. Apoptosis, cytotoxicity, and ROS production are concerns when exploring physiological effects of pharmacologically introduced bile acids; however, these effects are predominantly associated with concentrations exceeding physiological parameters [3]. Several bile acids have been used in the encapsulation of probucol with aims of improving targeted drug delivery. Numerous studies of this nature have shown significant benefits demonstrating bile acids as attractive excipients in the formation of nanocarriers for drug delivery [92,131,146-156]. When considering bile acids in the context of inner ear drug delivery, bile acids show promise in improving sustained and controlled drug release to the inner ear.

\subsection{Bile Acid Synthesis, Metabolism and Microbial Crosstalk}

Synthesis of primary bile acids involves over 17 enzymes via the following two potential pathways: the classical pathway and the alternative pathway. The classical pathway accounts for an excess of $90 \%$ of primary bile acid synthesis and begins with 
cholesterol $7 \alpha$ hydroxylase (CYP7A1) — mediated hydroxylation of cholesterol's C7 sterol ring. From this point, the determination of cholic acid (CA) or chenodeoxycholic acid (CDCA) production is established by the enzymatic activity of either $12 \alpha$ hydroxylase (CY8B1) or sterol 27-hydroxylase (CYP27), respectively. The alternative pathway mainly synthesizes CDCA via CYP27 and the subsequent oxysterol 7- $\alpha$ hydroxylase (CYP7B1)mediated transformation of cholesterol. Prior to release, enzymes acid-CoA:amino acid $\mathrm{N}$-acyltransferase and bile acid-CoA synthase conjugate CA and CDCA with either glycine or taurine, improving their pharmacokinetics properties for digestive function [144]. The conjugation of primary bile acids increases the hydrophilicity and side chain acidity in addition to lowering the approximate molecular pKa of the primary bile acids from 5.0 to $<2$ for taurine conjugates and 3.9 for glycine conjugates. The benefits of this include the increased hydrophilicity and ionization, and the associated reduction in the precipitation in acidic solutions, such as in the stomach [3].

Conjugated bile acids are released into the duodenum post food consumption, where the amphipathic structure and low pKa of the conjugated bile acids allows micelle formation to aid lipid and lipid-based vitamin digestion and absorption. A further transformation to the bile acids occurs within the colon. The local bacteria capable of expressing bile salt hydrolase deconjugate the glycine or taurine from the bile acids, then the bacterial expression of bile acid $7 \alpha$-dehydroxylase removes the $7 \alpha$ hydroxyl group from the deconjugated primary bile acids. The dehydroxylation of CA forms deoxycholic acid (DCA) and the dehydroxylation of CDCA forms lithocholic acid (LCA), both of which are more lipophilic than their primary bile acid counterparts. The lipophilicity of these bile acids is also associated with an increased membranolytic and toxic effect [157]. Throughout this process, conjugated bile acids are also being actively reabsorbed via apical sodium-dependent bile salt transporter for transport via the portal circulation back to the liver for reuse. Deconjugated bile acids are also capable of passively diffusing through the apical colon for reuse. Bile acid ligand biding to the hepatic farsenoid $X$ receptor (FXR) activates a pathway of signalling resulting in negative feedback to both CYP7A1 enzyme-expressing genes, preventing their transcription and, thus, preventing the synthesis of bile acid via cholesterol catabolism. This feedback system prevents the overproduction of bile acids that may reach toxic levels $[144,158]$.

\subsection{Bile Acids in Drug Delivery}

The secondary bile acid, DCA, is known for its ability to increase membrane permeability in various physiological settings [159-162]. A study by Lalić-Popović et al. [159] investigated the effects of DCA on the permeability of gliclazide across the blood-brain barrier in healthy and diabetic rats. The addition of DCA to gliclazide promoted the transport of gliclazide across the blood-brain barrier to a factor of three in healthy rats and a factor of four in diabetic rats [159]. Several studies have shown that the addition of DCA to drug carriers improves the mechanical and osmotic stability of drug carriers, improved controlled release delivery outcomes, and chemical stability with probucol addition $[93,130,132,136,148,154,163-179]$

Characterised as both a secondary and a tertiary bile acid [176,180,181], ursodeoxycholic acid (UDCA) has demonstrated antioxidant effects within the cochlea through the attenuation of miR-34a expression. Using C57BL/6 ARHL mice models and HEI-OC1 cell lines, Pang et al. analysed the relationships between miR-34a over-expression, regulatory autophagy activity, and the effects of UDCA within this context. Several key findings were revealed. Firstly, C57BL/ 6 mice models were effective models of ARHL. Secondly, miR-34a over-expression was significantly increased in the C57BL/ 6 model in comparison to the 1- and 3-month-old control mice. Thirdly, the transfection of HEI-OC1 cells suppresses regulatory autophagy, subsequently inducing cell death via the downregulation of ATGA9A. Finally, UDCA treatment significantly downregulated miR-34 expression and significantly reduced the cell death of miR-34-transfected cells [182]. UDCA incorporation into 
nano and micro capsule for drug delivery has demonstrated improved permeability [147] cytoprotective effects [183], and antioxidant effects [92,135,146,184-188].

Tauroursodeoxycholic acid (TUDCA) is formed by the conjugation of UDCA with taurine and has been shown to possess neuroprotective [189], hepatoprotective, and otoprotective effects [190]. TUDCA has been shown to attenuate the activation of all three pathways of the UPR response in small intestine Mode-K cells, inhibiting GRP78 gene expression [191]. In a murine model of nonsydromic autosomal recessive deafness induced via Cdh23 $3^{\text {erl/erl }}$ mutation, injections of TUDCA effectively ameliorated OHC apoptosis when compared to those injected with a phosphate buffer solution. The mechanism by which this occurs needs to be further explored, but the otoprotective effects were evident [190]. The incorporation of TUDCA in drug delivery has also demonstrated the permeating enhancing effects expected of bile acids [192]

LCA is produced in the colon via bacterial deconjugation [144]. In Caco-2 intestinal epithelial cells, this secondary bile acid prevented TNF- $\alpha$-induced epithelial damage. There was evidence of partial mediation via the downregulation of SIRT1-NRF2 pathways and the upregulation of NF- $\mathrm{KB}$ significantly attenuating ROS production and inflammation. This was achieved through the agonistic effects of LCA on the vitamin D receptor in the gastrointestinal tract [193]. The relationship between vitamin D and hearing loss has previously been explored [194]. Vitamin D receptor knockout mice show spiral ganglion degeneration, hair cell loss, increased cleaved caspase 3 biomarkers, and expression of the vitamin D receptor in the cochlea itself [195]. High levels of LCA have shown toxic effects in the body, specifically hepatotoxicity. Conversely, the incorporation of LCA in drug delivery systems has shown cytoprotective effects when encapsulating NIT-1 pancreas $\beta$-cells [92].

\section{Conclusions}

The increasing global prevalence of ARHL has influenced the focus of research with a growing need for answers and action. Identified via the utilisation of a search strategy implementing several databases, recent discoveries have further unravelled the complex and multifaceted pathogenesis of ARHL. In conjunction with this, the potential suitability of bile acid-based drug delivery mechanisms was explored in the context of antioxidantbased therapies as treatment for this disease. With the understanding of the pathogenesis of ARHL growing over time, the connection it holds with oxidative stress and chronic inflammation is becoming more apparent. These findings allow more efficacious pharmacologic interventions to be optioned as potential therapies. Several of the target molecules suggested in the recent literature for therapeutic intervention relate to the therapeutic mechanisms of action of common medications such as probucol and metformin; however, the need for a multifaceted approach to treatment still requires a suitable drug delivery system capable of delivering the required pharmaceutics to the affected areas. Systemic delivery of treatment drugs is the optimal choice when approaching from a patient compliance perspective, but, unfortunately, this is not a likely solution given the current state of biotechnology and understanding in this field. Thus, trends in inner ear drug delivery research show a heightened focus on local rather than systemic delivery, attempting to achieve sufficient therapeutic dosing within the cochlea whilst avoiding systemic side effects. Recent findings in bile acid incorporation in nano and micro drug delivery systems provide evidence supporting bile acids as excipients for several potential platforms for drug delivery into the inner ear. In addition, new research is emerging in the use of bile acids, such as TUDCA, as the therapeutic agent itself. Future research may benefit from exploring the therapeutic effects of bile acids in ARHL and how they may be utilised in improving drug delivery outcomes when aiming to overcome the anatomical barriers associated with inner ear drug delivery.

Author Contributions: Conceptualization, H.A.-S., A.M., M.M. and D.B.; methodology and software, J.C., E.J., D.W., M.J., C.M.I., S.R.W., and B.K.; writing—original draft preparation, J.C.; formal analysis, investigation, resources, data curation, and writing-review and editing, H.A.-S., A.M., M.M., D.B., 
J.C., E.J., D.W., M.J., C.M.I., S.R.W. and B.K. All authors have read and agreed to the published version of the manuscript.

Funding: The authors acknowledge Australian Postgraduate Award (APA) + Curtin Research Scholarship (CRS) for their support.

Conflicts of Interest: Al-Salami $\mathrm{H}$ has been and is currently receiving funding from Beijing Nat-Med Biotechnology Co. Ltd. and Glanis PTY Ltd. The funders had no role in the design of the study; in the collection, analyses, or interpretation of data; in the writing of the manuscript, or in the decision to publish the results.

\section{References}

1. Haile, L.M.; Kamenov, K.; Briant, P.S.; Orji, A.U.; Steinmetz, J.D.; Abdoli, A.; Abdollahi, M.; Abu-Gharbieh, E.; Afshin, A.; Ahmed, H.; et al. Hearing loss prevalence and years lived with disability, 1990-2019: Findings from the Global Burden of Disease Study 2019. Lancet 2021, 397, 996-1009. [CrossRef]

2. Tavanai, E.; Mohammadkhani, G. Role of antioxidants in prevention of age-related hearing loss: A review of literature. Eur. Arch. Otorhinolaryngol. 2017, 274, 1821-1834. [CrossRef]

3. Pavlovic, N.; Golocorbin-Kon, S.; Ethanic, M.; Stanimirov, B.; Al-Salami, H.; Stankov, K.; Mikov, M. Bile Acids and Their Derivatives as Potential Modifiers of Drug Release and Pharmacokinetic Profiles. Front. Pharmacol. 2018, 9, 1283. [CrossRef]

4. Møller, A.; Mller, A.R. Hearing: Anatomy, Physiology, and Disorders of the Auditory System, 3rd ed.; Plural Publishing, Incorporated: San Diego, CA, USA, 2012.

5. Costa, K.V.T.D.; Andrade, K.C.L.D.; Cavalcanti, M.E.D.; Frizzo, A.C.F.; Carnaúba, A.T.L.; Menezes, P.D.L. Hearing Loss at High Frequencies and Oxidative Stress: A New Paradigm for Different Etiologies. In An Excursus into Hearing Loss; Hatzopoulos, S., Ciorba, A., Eds.; IntechOpen: London, UK, 2018. [CrossRef]

6. Driver, E.C.; Kelley, M.W. Development of the cochlea. Development 2020, 147, dev162263. [CrossRef]

7. Nin, F.; Hibino, H.; Doi, K.; Suzuki, T.; Hisa, Y.; Kurachi, Y. The endocochlear potential depends on two K+ diffusion potentials and an electrical barrier in the stria vascularis of the inner ear. Proc. Natl. Acad. Sci. USA 2008, 105, 1751-1756. [CrossRef]

8. Anniko, M.; Wroblewski, R. Ionic environment of cochlear hair cells. Hear. Res. 1986, 22, 279-293. [CrossRef]

9. Behrbohm, H.; Nawka, T.; Kaschke, O. Ear, Nose and Throat Diseases, 3rd ed.; Thieme Medical Publishers, Inc.: New York, NY, USA, 2009; pp. 1-21. [CrossRef]

10. Fettiplace, R.; Kim, K.X. The physiology of mechanoelectrical transduction channels in hearing. Physiol. Rev. 2014, 94, 951-986. [CrossRef] [PubMed]

11. Cunningham, L.L.; Tucci, D.L. Hearing Loss in Adults. N. Engl. J. Med. 2017, 377, 2465-2473. [CrossRef] [PubMed]

12. McDaid, D.; Park, A.L.; Chadha, S. Estimating the global costs of hearing loss. Int. J. Audiol. 2021, 60, 162-170. [CrossRef] [PubMed]

13. Gates, G.A.; Mills, J.H. Presbycusis. Lancet 2005, 366, 1111-1120. [CrossRef]

14. Yang, C.H.; Schrepfer, T.; Schacht, J. Age-related hearing impairment and the triad of acquired hearing loss. Front. Cell Neurosci. 2015, 9, 276. [CrossRef] [PubMed]

15. Van Eyken, E.; Van Camp, G.; Van Laer, L. The complexity of age-related hearing impairment: Contributing environmental and genetic factors. Audiol. Neurootol. 2007, 12, 345-358. [CrossRef]

16. Rutherford, B.R.; Brewster, K.; Golub, J.S.; Kim, A.H.; Roose, S.P. Sensation and Psychiatry: Linking Age-Related Hearing Loss to Late-Life Depression and Cognitive Decline. Am. J. Psychiatry 2018, 175, 215-224. [CrossRef] [PubMed]

17. Livingston, G.; Sommerlad, A.; Orgeta, V.; Costafreda, S.G.; Huntley, J.; Ames, D.; Ballard, C.; Banerjee, S.; Burns, A.; CohenMansfield, J.; et al. Dementia prevention, intervention, and care. Lancet 2017, 390, 2673-2734. [CrossRef]

18. Lin, F.R.; Metter, E.J.; O’Brien, R.J.; Resnick, S.M.; Zonderman, A.B.; Ferrucci, L. Hearing loss and incident dementia. Arch. Neurol. 2011, 68, 214-220. [CrossRef]

19. Ciorba, A.; Bianchini, C.; Pelucchi, S.; Pastore, A. The impact of hearing loss on the quality of life of elderly adults. Clin. Interv. Aging 2012, 7, 159-163. [CrossRef] [PubMed]

20. Dawes, P.; Cruickshanks, K.J.; Moore, D.R.; Edmondson-Jones, M.; McCormack, A.; Fortnum, H.; Munro, K.J. Cigarette smoking, passive smoking, alcohol consumption, and hearing loss. J. Assoc. Res. Otolaryngol. 2014, 15, 663-674. [CrossRef] [PubMed]

21. Fulop, T.; Larbi, A.; Khalil, A.; Cohen, A.A.; Witkowski, J.M. Are We Ill Because We Age? Front. Physiol. 2019, 10, 1508. [CrossRef]

22. Harman, D. Aging: A theory based on free radical and radiation chemistry. J. Gerontol. 1956, 11, 298-300. [CrossRef]

23. Vina, J.; Borras, C.; Gomez-Cabrera, M.C. A free radical theory of frailty. Free Radic. Biol. Med. 2018, 124, 358-363. [CrossRef]

24. Menardo, J.; Tang, Y.; Ladrech, S.; Lenoir, M.; Casas, F.; Michel, C.; Bourien, J.; Ruel, J.; Rebillard, G.; Maurice, T.; et al. Oxidative stress, inflammation, and autophagic stress as the key mechanisms of premature age-related hearing loss in SAMP8 mouse Cochlea. Antioxid. Redox Signal. 2012, 16, 263-274. [CrossRef]

25. Keithley, E.M. Pathology and mechanisms of cochlear aging. J. Neurosci. Res. 2020, 98, 1674-1684. [CrossRef]

26. Sies, H.; Berndt, C.; Jones, D.P. Oxidative Stress. Annu. Rev. Biochem. 2017, 86, 715-748. [CrossRef]

27. Liguori, I.; Russo, G.; Curcio, F.; Bulli, G.; Aran, L.; Della-Morte, D.; Gargiulo, G.; Testa, G.; Cacciatore, F.; Bonaduce, D.; et al. Oxidative stress, aging, and diseases. Clin. Interv. Aging. 2018, 13, 757-772. [CrossRef] [PubMed] 
28. Bowl, M.R.; Dawson, S.J. Age-Related Hearing Loss. Cold Spring Harb. Perspect. Med. 2019, 9, a033217. [CrossRef] [PubMed]

29. Fetoni, A.R.; Picciotti, P.M.; Paludetti, G.; Troiani, D. Pathogenesis of presbycusis in animal models: A review. Exp. Gerontol. 2011, 46, 413-425. [CrossRef]

30. Chinnery, P.F. Mitochondrial disease in adults: What's old and what's new? EMBO Mol. Med. 2015, 7, 1503-1512. [CrossRef] [PubMed]

31. Tawfik, K.O.; Klepper, K.; Saliba, J.; Friedman, R.A. Advances in understanding of presbycusis. J. Neurosci. Res. 2020, 98, 1685-1697. [CrossRef] [PubMed]

32. Yamamoto, M.; Kensler, T.W.; Motohashi, H. The KEAP1-NRF2 System: A Thiol-Based Sensor-Effector Apparatus for Maintaining Redox Homeostasis. Physiol. Rev. 2018, 98, 1169-1203. [CrossRef]

33. Li, Y.; Zhao, X.; Hu, Y.; Sun, H.; He, Z.; Yuan, J.; Cai, H.; Sun, Y.; Huang, X.; Kong, W.; et al. Age-associated decline in Nrf2 signaling and associated mtDNA damage may be involved in the degeneration of the auditory cortex: Implications for central presbycusis. Int. J. Mol. Med. 2018, 42, 3371-3385. [CrossRef] [PubMed]

34. Dodson, M.; de la Vega, M.R.; Cholanians, A.B.; Schmidlin, C.J.; Chapman, E.; Zhang, D.D. Modulating NRF2 in Disease: Timing Is Everything. Annu. Rev. Pharmacol. Toxicol. 2019, 59, 555-575. [CrossRef] [PubMed]

35. Schmidlin, C.J.; Dodson, M.B.; Madhavan, L.; Zhang, D.D. Redox regulation by NRF2 in aging and disease. Free Radic. Biol. Med. 2019, 134, 702-707. [CrossRef] [PubMed]

36. Shaw, P.; Chattopadhyay, A. Nrf2-ARE signaling in cellular protection: Mechanism of action and the regulatory mechanisms. J. Cell Physiol. 2020, 235, 3119-3130. [CrossRef]

37. Oishi, T.; Matsumaru, D.; Ota, N.; Kitamura, H.; Zhang, T.; Honkura, Y.; Katori, Y.; Motohashi, H. Activation of the NRF2 pathway in Keap1-knockdown mice attenuates progression of age-related hearing loss. NPJ Aging Mech. Dis. 2020, 6, 14. [CrossRef] [PubMed]

38. Vilchis-Landeros, M.M.; Matuz-Mares, D.; Vazquez-Meza, H. Regulation of Metabolic Processes by Hydrogen Peroxide Generated by NADPH Oxidases. Processes 2020, 8, 1424. [CrossRef]

39. Paffenholz, R.; Bergstrom, R.A.; Pasutto, F.; Wabnitz, P.; Munroe, R.J.; Jagla, W.; Heinzmann, U.; Marquardt, A.; Bareiss, A.; Laufs, J.; et al. Vestibular defects in head-tilt mice result from mutations in Nox3, encoding an NADPH oxidase. Genes Dev. 2004, 18, 486-491. [CrossRef] [PubMed]

40. Rousset, F.; Nacher-Soler, G.; Coelho, M.; Ilmjarv, S.; Kokje, V.B.C.; Marteyn, A.; Cambet, Y.; Perny, M.; Roccio, M.; Jaquet, V.; et al. Redox activation of excitatory pathways in auditory neurons as mechanism of age-related hearing loss. Redox Biol. 2020, 30, 101434. [CrossRef]

41. Sanada, F.; Taniyama, Y.; Muratsu, J.; Otsu, R.; Shimizu, H.; Rakugi, H.; Morishita, R. Source of Chronic Inflammation in Aging. Front. Cardiovasc. Med. 2018, 5, 12. [CrossRef]

42. Watson, N.; Ding, B.; Zhu, X.; Frisina, R.D. Chronic inflammation-inflammaging-in the ageing cochlea: A novel target for future presbycusis therapy. Ageing Res. Rev. 2017, 40, 142-148. [CrossRef]

43. Warraich, U.E.; Hussain, F.; Kayani, H.U.R. Aging-Oxidative stress, antioxidants and computational modeling. Heliyon 2020, 6 , e04107. [CrossRef]

44. Neves, J.; Sousa-Victor, P. Regulation of inflammation as an anti-aging intervention. FEBS J. 2020, 287, 43-52. [CrossRef]

45. Krabbe, K.S.; Pedersen, M.; Bruunsgaard, H. Inflammatory mediators in the elderly. Exp. Gerontol. 2004, 39, 687-699. [CrossRef]

46. Prasad, K.N.; Bondy, S.C. Increased oxidative stress, inflammation, and glutamate: Potential preventive and therapeutic targets for hearing disorders. Mech. Ageing Dev. 2020, 185, 111191. [CrossRef] [PubMed]

47. Kanigur Sultuybek, G.; Soydas, T.; Yenmis, G. NF-kappaB as the mediator of metformin's effect on ageing and ageing-related diseases. Clin. Exp. Pharmacol. Physiol. 2019, 46, 413-422. [CrossRef] [PubMed]

48. Blaser, H.; Dostert, C.; Mak, T.W.; Brenner, D. TNF and ROS Crosstalk in Inflammation. Trends Cell Biol. 2016, 26, $249-261$. [CrossRef] [PubMed]

49. Katsumi, S.; Sahin, M.I.; Lewis, R.M.; Iyer, J.S.; Landegger, L.D.; Stankovic, K.M. Intracochlear Perfusion of Tumor Necrosis Factor-Alpha Induces Sensorineural Hearing Loss and Synaptic Degeneration in Guinea Pigs. Front. Neurol. $2019,10,1353$. [CrossRef] [PubMed]

50. Lingappan, K. NF-kappaB in Oxidative Stress. Curr. Opin. Toxicol. 2018, 7, 81-86. [CrossRef]

51. Du, Z.D.; Han, S.G.; Qu, T.F.; Guo, B.; Yu, S.K.; Wei, W.; Feng, S.; Liu, K.; Gong, S.S. Age-related insult of cochlear ribbon synapses: An early-onset contributor to D-galactose-induced aging in mice. Neurochem. Int. 2020, 133, 104649. [CrossRef]

52. Morrill, S.; He, D.Z.Z. Apoptosis in inner ear sensory hair cells. J. Otol. 2017, 12, 151-164. [CrossRef]

53. Wu, J.; Ye, J.; Kong, W.; Zhang, S.; Zheng, Y. Programmed cell death pathways in hearing loss: A review of apoptosis, autophagy and programmed necrosis. Cell Prolif. 2020, 53, e12915. [CrossRef] [PubMed]

54. Du, Z.; Yang, Q.; Liu, L.; Li, S.; Zhao, J.; Hu, J.; Liu, C.; Qian, D.; Gao, C. NADPH oxidase 2-dependent oxidative stress, mitochondrial damage and apoptosis in the ventral cochlear nucleus of D-galactose-induced aging rats. Neuroscience 2015, 286, 281-292. [CrossRef]

55. Kong, W.J.; Wang, Y.; Wang, Q.; Hu, Y.J.; Han, Y.C.; Liu, J. The relation between D-galactose injection and mitochondrial DNA 4834 bp deletion mutation. Exp. Gerontol. 2006, 41, 628-634. [CrossRef] 
56. Zhong, Y.; Hu, Y.J.; Chen, B.; Peng, W.; Sun, Y.; Yang, Y.; Zhao, X.Y.; Fan, G.R.; Huang, X.; Kong, W.J. Mitochondrial transcription factor A overexpression and base excision repair deficiency in the inner ear of rats with D-galactose-induced aging. FEBS J. 2011, 278, 2500-2510. [CrossRef] [PubMed]

57. Du, Z.; Yang, Y.; Hu, Y.; Sun, Y.; Zhang, S.; Peng, W.; Zhong, Y.; Huang, X.; Kong, W. A long-term high-fat diet increases oxidative stress, mitochondrial damage and apoptosis in the inner ear of D-galactose-induced aging rats. Hear. Res. 2012, 287, 15-24. [CrossRef]

58. Someya, S.; Prolla, T.A. Mitochondrial oxidative damage and apoptosis in age-related hearing loss. Mech. Ageing Dev. 2010, 131, 480-486. [CrossRef] [PubMed]

59. Someya, S.; Xu, J.; Kondo, K.; Ding, D.; Salvi, R.J.; Yamasoba, T.; Rabinovitch, P.S.; Weindruch, R.; Leeuwenburgh, C.; Tanokura, M.; et al. Age-related hearing loss in C57BL/6J mice is mediated by Bak-dependent mitochondrial apoptosis. Proc. Natl. Acad. Sci. USA 2009, 106, 19432-19437. [CrossRef]

60. Ye, B.; Fan, C.; Shen, Y.; Wang, Q.; Hu, H.; Xiang, M. The Antioxidative Role of Autophagy in Hearing Loss. Front. Neurosci. 2018, 12, 1010. [CrossRef]

61. Kosztelnik, M.; Kurucz, A.; Papp, D.; Jones, E.; Sigmond, T.; Barna, J.; Traka, M.H.; Lorincz, T.; Szarka, A.; Banhegyi, G.; et al. Suppression of AMPK/aak-2 by NRF2/SKN-1 down-regulates autophagy during prolonged oxidative stress. FASEB J. 2019, 33, 2372-2387. [CrossRef] [PubMed]

62. De Iriarte Rodriguez, R.; Pulido, S.; Rodriguez-de la Rosa, L.; Magarinos, M.; Varela-Nieto, I. Age-regulated function of autophagy in the mouse inner ear. Hear. Res. 2015, 330, 39-50. [CrossRef]

63. Wang, W.; Sun, Y.; Chen, S.; Zhou, X.; Wu, X.; Kong, W.; Kong, W. Impaired unfolded protein response in the degeneration of cochlea cells in a mouse model of age-related hearing loss. Exp. Gerontol. 2015, 70, 61-70. [CrossRef]

64. Jung, S.Y.; Kim, S.S.; Yeo, S.G. Impact of Endoplasmic Reticulum Stress in Otorhinolaryngologic Diseases. Int. J. Mol. Sci. 2020, 21, 4121. [CrossRef]

65. Horikawa, C.; Kodama, S.; Tanaka, S.; Fujihara, K.; Hirasawa, R.; Yachi, Y.; Shimano, H.; Yamada, N.; Saito, K.; Sone, H. Diabetes and risk of hearing impairment in adults: A meta-analysis. J. Clin. Endocrinol. Metab. 2013, 98, 51-58. [CrossRef] [PubMed]

66. Lee, Y.Y.; Kim, Y.J.; Gil, E.S.; Kim, H.; Jang, J.H.; Choung, Y.H. Type 1 Diabetes Induces Hearing Loss: Functional and Histological Findings in An Akita Mouse Model. Biomedicines 2020, 8. [CrossRef]

67. Parmar, S.M.; Khare, P.; Chaudhary, M. Evaluation of Effects of Diabetes Mellitus Type 2 and Hyperlipidemia on Hearing. Indian J. Otol. 2017, 23, 155-161. [CrossRef]

68. Takechi, R.; Lam, V.; Brook, E.; Giles, C.; Fimognari, N.; Mooranian, A.; Al-Salami, H.; Coulson, S.H.; Nesbit, M.; Mamo, J.C.L. Blood-Brain Barrier Dysfunction Precedes Cognitive Decline and Neurodegeneration in Diabetic Insulin Resistant Mouse Model: An Implication for Causal Link. Front. Aging Neurosci. 2017, 9, 399. [CrossRef] [PubMed]

69. Yadav, M.K.; Yadav, K.S. Etiology of Noise-Induced Hearing Loss (NIHL) and its Symptomatic Correlation with Audiometry Observations in Type II Diabetes. Indian J. Otolaryngol. Head Neck Surg. 2018, 70, 137-144. [CrossRef]

70. Shen, Y.; Ye, B.; Chen, P.; Wang, Q.; Fan, C.; Shu, Y.; Xiang, M. Cognitive Decline, Dementia, Alzheimer's Disease and Presbycusis: Examination of the Possible Molecular Mechanism. Front. Neurosci. 2018, 12, 394. [CrossRef]

71. Ighodaro, O.M. Molecular pathways associated with oxidative stress in diabetes mellitus. Biomed. Pharmacother. 2018, 108, 656-662. [CrossRef]

72. Zhang, F.; Kerbl-Knapp, J.; Akhmetshina, A.; Korbelius, M.; Kuentzel, K.B.; Vujic, N.; Horl, G.; Paar, M.; Kratky, D.; Steyrer, E.; et al. Tissue-Specific Landscape of Metabolic Dysregulation during Ageing. Biomolecules 2021, 11, 235. [CrossRef]

73. Marie, A.; Larroze-Chicot, P.; Cosnier-Pucheu, S.; Gonzalez-Gonzalez, S. Senescence-accelerated mouse prone 8 (SAMP8) as a model of age-related hearing loss. Neurosci. Lett. 2017, 656, 138-143. [CrossRef]

74. Akiguchi, I.; Pallas, M.; Budka, H.; Akiyama, H.; Ueno, M.; Han, J.; Yagi, H.; Nishikawa, T.; Chiba, Y.; Sugiyama, H.; et al. SAMP8 mice as a neuropathological model of accelerated brain aging and dementia: Toshio Takeda's legacy and future directions. Neuropathology 2017, 37, 293-305. [CrossRef]

75. Rhea, E.M.; Banks, W.A. The SAMP8 mouse for investigating memory and the role of insulin in the brain. Exp. Gerontol. 2017, 94, 64-68. [CrossRef]

76. Mironczuk-Chodakowska, I.; Witkowska, A.M.; Zujko, M.E. Endogenous non-enzymatic antioxidants in the human body. Adv. Med. Sci. 2018, 63, 68-78. [CrossRef]

77. Pak, J.H.; Kim, Y.; Yi, J.; Chung, J.W. Antioxidant Therapy against Oxidative Damage of the Inner Ear: Protection and Preconditioning. Antioxidants 2020, 9, 1076. [CrossRef]

78. Mbara, K.C.; Mofo Mato, P.E.; Driver, C.; Nzuza, S.; Mkhombo, N.T.; Gcwensa, S.K.; McObothi, E.N.; Owira, P.M. Metformin turns 62 in pharmacotherapy: Emergence of non-glycaemic effects and potential novel therapeutic applications. Eur. J. Pharmacol. 2021, 898, 173934. [CrossRef]

79. Gedawy, A.; Al-Salami, H.; Dass, C.R. Role of metformin in various pathologies: State-of-the-art microcapsules for improving its pharmacokinetics. Ther. Deliv. 2020, 11,733-753. [CrossRef]

80. Cai, H.; Han, B.; Hu, Y.; Zhao, X.; He, Z.; Chen, X.; Sun, H.; Yuan, J.; Li, Y.; Yang, X.; et al. Metformin attenuates the Dgalactoseinduced aging process via the UPR through the AMPK/ERK1/2 signaling pathways. Int. J. Mol. Med. 2020, 45, 715-730. [CrossRef] 
81. Yang, S.; Zhao, L.; Han, Y.; Liu, Y.; Chen, C.; Zhan, M.; Xiong, X.; Zhu, X.; Xiao, L.; Hu, C.; et al. Probucol ameliorates renal injury in diabetic nephropathy by inhibiting the expression of the redox enzyme p66Shc. Redox Biol. 2017, 13, 482-497. [CrossRef] [PubMed]

82. Zhou, G.; Wang, Y.; He, P.; Li, D. Probucol inhibited Nox2 expression and attenuated podocyte injury in type 2 diabetic nephropathy of db/db mice. Biol. Pharm. Bull. 2013, 36, 1883-1890. [CrossRef] [PubMed]

83. Zhou, Z.; Liu, C.; Chen, S.; Zhao, H.; Zhou, K.; Wang, W.; Yuan, Y.; Li, Z.; Guo, Y.; Shen, Z.; et al. Activation of the Nrf2/ARE signaling pathway by probucol contributes to inhibiting inflammation and neuronal apoptosis after spinal cord injury. Oncotarget 2017, 8, 52078-52093. [CrossRef] [PubMed]

84. Ma, X.; Jiao, Z.; Liu, Y.; Chen, J.; Li, G.; Liu, T.; Tse, G.; Yuan, R. Probucol Protects Against Contrast-Induced Acute Kidney Injury via the Extracellular Signal-Regulated Kinases 1 and 2 (ERK1/2)/JNK-Caspase 3 Pathway in Diabetic Rats. Med. Sci. Monit. 2019, 25, 1038-1045. [CrossRef]

85. Mir, H.A.; Ali, R.; Mushtaq, U.; Khanday, F.A. Structure-functional implications of longevity protein p66Shc in health and disease. Ageing Res. Rev. 2020, 63, 101139. [CrossRef]

86. Asiri, Y.A. Probucol attenuates cyclophosphamide-induced oxidative apoptosis, p53 and Bax signal expression in rat cardiac tissues. Oxid. Med. Cell Longev. 2010, 3, 308-316. [CrossRef]

87. Zhou, X.; Ai, S.; Chen, Z.; Li, C. Probucol promotes high glucose-induced proliferation and inhibits apoptosis by reducing reactive oxygen species generation in Muller cells. Int. Ophthalmol. 2019, 39, 2833-2842. [CrossRef] [PubMed]

88. Hu, L.L.; Zhang, K.Q.; Tian, T.; Zhang, H.; Fu, Q. Probucol improves erectile function via Activation of Nrf2 and coordinates the HO-1 / DDAH / PPAR-gamma/ eNOS pathways in streptozotocin-induced diabetic rats. Biochem. Biophys. Res. Commun. 2018, 507, 9-14. [CrossRef] [PubMed]

89. Chen, C.; Wang, Y.; Cao, Y.; Wang, Q.; Anwaier, G.; Zhang, Q.; Qi, R. Mechanisms underlying the inhibitory effects of probucol on elastase-induced abdominal aortic aneurysm in mice. Br. J. Pharmacol. 2020, 177, 204-216. [CrossRef] [PubMed]

90. Motterlini, R.; Foresti, R. Heme oxygenase-1 as a target for drug discovery. Antioxid. Redox. Signal. 2014, 20, 1810-1826. [CrossRef] [PubMed]

91. Wu, R.; Zhang, W.; Liu, B.; Gao, J.; Xiao, X.Q.; Zhang, F.; Zhou, H.M.; Wu, X.L.; Zhang, X. Probucol ameliorates the development of nonalcoholic steatohepatitis in rats fed high-fat diets. Dig. Dis. Sci. 2013, 58, 163-171. [CrossRef]

92. Wagle, S.R.; Walker, D.; Kovacevic, B.; Gedawy, A.; Mikov, M.; Golocorbin-Kon, S.; Mooranian, A.; Al-Salami, H. Micro-Nano formulation of bile-gut delivery: Rheological, stability and cell survival, basal and maximum respiration studies. Sci. Rep. 2020, 10, 7715. [CrossRef]

93. Wagle, S.R.; Kovacevic, B.; Walker, D.; Ionescu, C.M.; Jones, M.; Stojanovic, G.; Kojic, S.; Mooranian, A.; Al-Salami, H. Pharmacological and Advanced Cell Respiration Effects, Enhanced by Toxic Human-Bile Nano-Pharmaceuticals of Probucol Cell-Targeting Formulations. Pharmaceutics 2020, 12, 708. [CrossRef]

94. Yamashita, S.; Matsuzawa, Y. Where are we with probucol: A new life for an old drug? Atherosclerosis 2009, 207, 16-23. [CrossRef] [PubMed]

95. Jaudoin, C.; Agnely, F.; Nguyen, Y.; Ferrary, E.; Bochot, A. Nanocarriers for drug delivery to the inner ear: Physicochemical key parameters, biodistribution, safety and efficacy. Int. J. Pharm. 2021, 592, 120038. [CrossRef] [PubMed]

96. Zeb, A.; Rana, I.; Choi, H.I.; Lee, C.H.; Baek, S.W.; Lim, C.W.; Khan, N.; Arif, S.T.; Sahar, N.U.; Alvi, A.M.; et al. Potential and Applications of Nanocarriers for Efficient Delivery of Biopharmaceuticals. Pharmaceutics 2020, 12, 1184. [CrossRef]

97. Glueckert, R.; Johnson Chacko, L.; Rask-Andersen, H.; Liu, W.; Handschuh, S.; Schrott-Fischer, A. Anatomical basis of drug delivery to the inner ear. Hear. Res. 2018, 368, 10-27. [CrossRef] [PubMed]

98. Liu, X.; Li, M.; Smyth, H.; Zhang, F. Otic drug delivery systems: Formulation principles and recent developments. Drug Dev. Ind. Pharm. 2018, 44, 1395-1408. [CrossRef] [PubMed]

99. Nyberg, S.; Abbott, N.J.; Shi, X.; Steyger, P.S.; Dabdoub, A. Delivery of therapeutics to the inner ear: The challenge of the blood-labyrinth barrier. Sci. Transl. Med. 2019, 11, eaao0935. [CrossRef]

100. El Kechai, N.; Agnely, F.; Mamelle, E.; Nguyen, Y.; Ferrary, E.; Bochot, A. Recent advances in local drug delivery to the inner ear. Int. J. Pharm. 2015, 494, 83-101. [CrossRef]

101. Chandrasekhar, S.S.; Tsai Do, B.S.; Schwartz, S.R.; Bontempo, L.J.; Faucett, E.A.; Finestone, S.A.; Hollingsworth, D.B.; Kelley, D.M.; Kmucha, S.T.; Moonis, G.; et al. Clinical Practice Guideline: Sudden Hearing Loss (Update). Otolaryngol. Head Neck Surg. 2019, 161, S1-S45. [CrossRef] [PubMed]

102. Goycoolea, M.V. Clinical aspects of round window membrane permeability under normal and pathological conditions. Acta Otolaryngol. 2001, 121, 437-447. [CrossRef]

103. Sahni, R.S.; Paparella, M.M.; Schachern, P.A.; Goycoolea, M.V.; Le, C.T. Thickness of the human round window membrane in different forms of otitis media. Arch. Otolaryngol. Head Neck Surg. 1987, 113, 630-634. [CrossRef]

104. Schachern, P.A.; Paparella, M.M.; Goycoolea, M.V.; Duvall, A.J., 3rd; Choo, Y.B. The permeability of the round window membrane during otitis media. Arch. Otolaryngol. Head Neck Surg. 1987, 113, 625-629. [CrossRef]

105. Luers, J.C.; Huttenbrink, K.B.; Beutner, D. Surgical anatomy of the round window-Implications for cochlear implantation. Clin. Otolaryngol. 2018, 43, 417-424. [CrossRef]

106. Zou, J.; Sood, R.; Ranjan, S.; Poe, D.; Ramadan, U.A.; Pyykko, I.; Kinnunen, P.K. Size-dependent passage of liposome nanocarriers with preserved posttransport integrity across the middle-inner ear barriers in rats. Otol. Neurotol. 2012, 33, 666-673. [CrossRef] 
107. Cai, H.; Liang, Z.; Huang, W.; Wen, L.; Chen, G. Engineering PLGA nano-based systems through understanding the influence of nanoparticle properties and cell-penetrating peptides for cochlear drug delivery. Int. J. Pharm. 2017, 532, 55-65. [CrossRef]

108. Liu, H.; Chen, S.; Zhou, Y.; Che, X.; Bao, Z.; Li, S.; Xu, J. The effect of surface charge of glycerol monooleate-based nanoparticles on the round window membrane permeability and cochlear distribution. J. Drug. Target. 2013, 21, 846-854. [CrossRef]

109. Goycoolea, M.V.; Muchow, D.; Martinez, G.C.; Aguila, P.B.; Goycoolea, H.G.; Goycoolea, C.V.; Schachern, P.; Knight, W. Permeability of the human round-window membrane to cationic ferritin. Arch. Otolaryngol. Head Neck Surg. 1988, 114, 1247-1251. [CrossRef] [PubMed]

110. Wang, X.; Dellamary, L.; Fernandez, R.; Ye, Q.; LeBel, C.; Piu, F. Principles of inner ear sustained release following intratympanic administration. Laryngoscope 2011, 121, 385-391. [CrossRef]

111. Mikulec, A.A.; Hartsock, J.J.; Salt, A.N. Permeability of the round window membrane is influenced by the composition of applied drug solutions and by common surgical procedures. Otol. Neurotol. 2008, 29, 1020-1026. [CrossRef] [PubMed]

112. Szeto, B.; Chiang, H.; Valentini, C.; Yu, M.; Kysar, J.W.; Lalwani, A.K. Inner ear delivery: Challenges and opportunities. Laryngoscope Investig. Otolaryngol. 2020, 5, 122-131. [CrossRef] [PubMed]

113. Rathnam, C.; Chueng, S.D.; Ying, Y.M.; Lee, K.B.; Kwan, K. Developments in Bio-Inspired Nanomaterials for Therapeutic Delivery to Treat Hearing Loss. Front. Cell Neurosci. 2019, 13, 493. [CrossRef]

114. Patel, J.; Szczupak, M.; Rajguru, S.; Balaban, C.; Hoffer, M.E. Inner Ear Therapeutics: An Overview of Middle Ear Delivery. Front. Cell Neurosci. 2019, 13, 261. [CrossRef]

115. Mittal, R.; Pena, S.A.; Zhu, A.; Eshraghi, N.; Fesharaki, A.; Horesh, E.J.; Mittal, J.; Eshraghi, A.A. Nanoparticle-based drug delivery in the inner ear: Current challenges, limitations and opportunities. Artif. Cells Nanomed. Biotechnol. 2019, 47, 1312-1320. [CrossRef]

116. Zhang, L.; Xu, Y.; Cao, W.; Xie, S.; Wen, L.; Chen, G. Understanding the translocation mechanism of PLGA nanoparticles across round window membrane into the inner ear: A guideline for inner ear drug delivery based on nanomedicine. Int. J. Nanomed. 2018, 13, 479-492. [CrossRef] [PubMed]

117. Silverstein, H.; Thompson, J.; Rosenberg, S.I.; Brown, N.; Light, J. Silverstein MicroWick. Otolaryngol. Clin. N. Am. 2004, 37, 1019-1034. [CrossRef]

118. Hill, A.; Geissler, S.; Meyring, M.; Hecht, S.; Weigandt, M.; Mader, K. In vitro-in vivo evaluation of nanosuspension release from subcutaneously implantable osmotic pumps. Int. J. Pharm. 2013, 451, 57-66. [CrossRef] [PubMed]

119. Hill, A.; Breyer, S.; Geissler, S.; Mier, W.; Haberkorn, U.; Weigandt, M.; Mader, K. How do in-vitro release profiles of nanosuspensions from Alzet(R) pumps correspond to the in-vivo situation? A case study on radiolabeled fenofibrate. J. Control. Release 2013, 168, 77-87. [CrossRef] [PubMed]

120. El Kechai, N.; Mamelle, E.; Nguyen, Y.; Huang, N.; Nicolas, V.; Chaminade, P.; Yen-Nicolay, S.; Gueutin, C.; Granger, B.; Ferrary, E.; et al. Hyaluronic acid liposomal gel sustains delivery of a corticoid to the inner ear. J. Control. Release 2016, 226, 248-257. [CrossRef] [PubMed]

121. Dai, J.; Long, W.; Liang, Z.; Wen, L.; Yang, F.; Chen, G. A novel vehicle for local protein delivery to the inner ear: Injectable and biodegradable thermosensitive hydrogel loaded with PLGA nanoparticles. Drug Dev. Ind. Pharm. 2018, 44, 89-98. [CrossRef] [PubMed]

122. Engmer Berglin, C.; Videhult Pierre, P.; Ekborn, A.; Bramer, T.; Edsman, K.; Hultcrantz, M.; Laurell, G. Local treatment of the inner ear: A study of three different polymers aimed for middle ear administration. Acta. Otolaryngol. 2015, 135, 985-994. [CrossRef] [PubMed]

123. Havenith, S.; Versnel, H.; Agterberg, M.J.; de Groot, J.C.; Sedee, R.J.; Grolman, W.; Klis, S.F. Spiral ganglion cell survival after round window membrane application of brain-derived neurotrophic factor using gelfoam as carrier. Hear. Res. 2011, 272, 168-177. [CrossRef]

124. Silverstein, H.; Arruda, J.; Rosenberg, S.I.; Deems, D.; Hester, T.O. Direct round window membrane application of gentamicin in the treatment of Meniere's disease. Otolaryngol. Head Neck Surg. 1999, 120, 649-655. [CrossRef] [PubMed]

125. Takeda, H.; Kurioka, T.; Kaitsuka, T.; Tomizawa, K.; Matsunobu, T.; Hakim, F.; Mizutari, K.; Miwa, T.; Yamada, T.; Ise, M.; et al. Protein transduction therapy into cochleae via the round window niche in guinea pigs. Mol. Ther. Methods Clin. Dev. 2016, 3, 16055. [CrossRef] [PubMed]

126. Mader, K.; Lehner, E.; Liebau, A.; Plontke, S.K. Controlled drug release to the inner ear: Concepts, materials, mechanisms, and performance. Hear. Res. 2018, 368, 49-66. [CrossRef] [PubMed]

127. Wen, X.; Ding, S.; Cai, H.; Wang, J.; Wen, L.; Yang, F.; Chen, G. Nanomedicine strategy for optimizing delivery to outer hair cells by surface-modified poly(lactic/glycolic acid) nanoparticles with hydrophilic molecules. Int. J. Nanomed. 2016, 11, 5959-5969. [CrossRef]

128. Lajud, S.A.; Nagda, D.A.; Qiao, P.; Tanaka, N.; Civantos, A.; Gu, R.; Cheng, Z.; Tsourkas, A.; O’Malley, B.W., Jr.; Li, D. A novel chitosan-hydrogel-based nanoparticle delivery system for local inner ear application. Otol. Neurotol. 2015, 36, 341-347. [CrossRef]

129. Wong, C.Y.; Al-Salami, H.; Dass, C.R. Microparticles, microcapsules and microspheres: A review of recent developments and prospects for oral delivery of insulin. Int. J. Pharm. 2018, 537, 223-244. [CrossRef]

130. Mooranian, A.; Zamani, N.; Mikov, M.; Goločorbin-Kon, S.; Stojanovic, G.; Arfuso, F.; Al-Salami, H. Eudragit ${ }^{\circledR}$-based microcapsules of probucol with a gut-bacterial processed secondary bile acid. Ther. Deliv. 2018, 9, 811-821. [CrossRef] 
131. Mooranian, A.; Negrulj, R.; Takechi, R.; Jamieson, E.; Morahan, G.; Al-Salami, H. Influence of Biotechnological Processes, Speed of Formulation Flow and Cellular Concurrent Stream-Integration on Insulin Production from $\mathrm{I}^{2}$-cells as a Result of Co-Encapsulation with a Highly Lipophilic Bile Acid. Cell. Mol. Bioeng. 2018, 11, 65-75. [CrossRef]

132. Mamo, J.C.; Lam, V.; Al-Salami, H.; Brook, E.; Mooranian, A.; Nesbit, M.; Graneri, L.; D'Alonzo, Z.; Fimognari, N.; Stephenson, A.; et al. Sodium alginate capsulation increased brain delivery of probucol and suppressed neuroinflammation and neurodegeneration. Ther. Deliv. 2018, 9, 703-709. [CrossRef]

133. Bakry, A.M.; Abbas, S.; Ali, B.; Majeed, H.; Abouelwafa, M.Y.; Mousa, A.; Liang, L. Microencapsulation of Oils: A Comprehensive Review of Benefits, Techniques, and Applications. Compr. Rev. Food Sci. Food Saf. 2016, 15, 143-182. [CrossRef]

134. Pritz, C.O.; Dudas, J.; Rask-Andersen, H.; Schrott-Fischer, A.; Glueckert, R. Nanomedicine strategies for drug delivery to the ear. Nanomedicine 2013, 8, 1155-1172. [CrossRef]

135. Jones, M.; Walker, D.; Ionescu, C.M.; Kovacevic, B.; Wagle, S.R.; Mooranian, A.; Brown, D.; Al-Salami, H. Microencapsulation of Coenzyme Q10 and bile acids using ionic gelation vibrational jet flow technology for oral delivery. Ther. Deliv. 2020, 11, 791-805. [CrossRef]

136. Mooranian, A.; Zamani, N.; Takechi, R.; Al-Sallami, H.; Mikov, M.; Goločorbin-Kon, S.; Kovacevic, B.; Arfuso, F.; Al-Salami, H. Probucol-poly(meth)acrylate-bile acid nanoparticles increase IL-10, and primary bile acids in prediabetic mice. Ther. Deliv. 2019, 10, 563-571. [CrossRef] [PubMed]

137. Mooranian, A.; Zamani, N.; Luna, G.; Al-Sallami, H.; Mikov, M.; Goločorbin-Kon, S.; Stojanovic, G.; Arfuso, F.; Kovacevic, B.; Al-Salami, H. Bile acid-polymer-probucol microparticles: Protective effect on pancreatic $\beta$-cells and decrease in type 1 diabetes development in a murine model. Pharm. Dev. Technol. 2019, 24, 1272-1277. [CrossRef]

138. Mathavan, S.; Ionescu, C.M.; Kovacevic, B.; Mikov, M.; Golocorbin-Kon, S.; Mooranian, A.; Dass, C.R.; Al-Salami, H. Formulation buoyancy of nanoencapsulated gliclazide using primary, conjugated and deconjugated bile acids. Ther. Deliv. 2019, 10, 573-583. [CrossRef] [PubMed]

139. Li, L.; Chao, T.; Brant, J.; O'Malley, B., Jr.; Tsourkas, A.; Li, D. Advances in nano-based inner ear delivery systems for the treatment of sensorineural hearing loss. Adv. Drug Deliv. Rev. 2017, 108, 2-12. [CrossRef] [PubMed]

140. Fakhoury, M.; Negrulj, R.; Mooranian, A.; Al-Salami, H. Inflammatory bowel disease: Clinical aspects and treatments. J. Inflamm. Res. 2014, 7, 113-120. [CrossRef] [PubMed]

141. Negrulj, R.; Mooranian, A.; Al-Salami, H. Potentials and Limitations of Bile Acids in Type 2 Diabetes Mellitus: Applications of Microencapsulation as a Novel Oral Delivery System. J. Endocrinol. Diabetes Mellit. 2013, 1, 49-59.

142. Ethanic, M.; Stanimirov, B.; Pavlovic, N.; Golocorbin-Kon, S.; Al-Salami, H.; Stankov, K.; Mikov, M. Pharmacological Applications of Bile Acids and Their Derivatives in the Treatment of Metabolic Syndrome. Front. Pharmacol. 2018, 9, 1382. [CrossRef]

143. Woodhams, L.; Al-Salami, H. The roles of bile acids and applications of microencapsulation technology in treating Type 1 diabetes mellitus. Ther. Deliv. 2017, 8, 401-409. [CrossRef] [PubMed]

144. Di Gregorio, M.C.; Cautela, J.; Galantini, L. Physiology and Physical Chemistry of Bile Acids. Int. J. Mol. Sci. 2021, 22, 1780. [CrossRef] [PubMed]

145. Mooranian, A.; Negrulj, R.; Mikov, M.; Golocorbin-Kon, S.; Arfuso, F.; Al-Salami, H. Novel chenodeoxycholic acid-sodium alginate matrix in the microencapsulation of the potential antidiabetic drug, probucol. An in vitro study. J. Microencapsul. 2015, 32, 589-597. [CrossRef]

146. Mooranian, A.; Raj Wagle, S.; Kovacevic, B.; Takechi, R.; Mamo, J.; Lam, V.; Watts, G.F.; Mikov, M.; Golocorbin-Kon, S.; Stojanovic, G.; et al. Bile acid bio-nanoencapsulation improved drug targeted-delivery and pharmacological effects via cellular flux: 6-months diabetes preclinical study. Sci. Rep. 2020, 10, 106. [CrossRef]

147. Mooranian, A.; Zamani, N.; Mikov, M.; Golocorbin-Kon, S.; Stojanovic, G.; Arfuso, F.; Kovacevic, B.; Al-Salami, H. Bio Micro-Nano Technologies of Antioxidants Optimised Their Pharmacological and Cellular Effects, ex vivo, in Pancreatic beta-Cells. Nanotechnol. Sci. Appl. 2020, 13, 1-9. [CrossRef]

148. Mooranian, A.; Negrulj, R.; Arfuso, F.; Al-Salami, H. Multicompartmental, multilayered probucol microcapsules for diabetes mellitus: Formulation characterization and effects on production of insulin and inflammation in a pancreatic beta-cell line. Artif. Cells Nanomed. Biotechnol. 2016, 44, 1642-1653. [CrossRef]

149. Mooranian, A.; Zamani, N.; Mikov, M.; Golocorbin-Kon, S.; Stojanovic, G.; Arfuso, F.; Al-Salami, H. Novel nano-encapsulation of probucol in microgels: Scanning electron micrograph characterizations, buoyancy profiling, and antioxidant assay analyses. Artif. Cells Nanomed. Biotechnol. 2018, 46, S741-S747. [CrossRef]

150. Mooranian, A.; Zamani, N.; Mikov, M.; Golocorbin-Kon, S.; Stojanovic, G.; Arfuso, F.; Kovacevic, B.; Al-Salami, H. A secondgeneration micro/nano capsules of an endogenous primary un-metabolised bile acid, stabilized by Eudragit-alginate complex with antioxidant compounds. Saudi. Pharm. J. 2020, 28, 165-171. [CrossRef] [PubMed]

151. Mooranian, A.; Negrulj, R.; Al-Salami, H. The influence of stabilized deconjugated ursodeoxycholic acid on polymer-hydrogel system of transplantable NIT-1 cells. Pharm. Res. 2016, 33, 1182-1190. [CrossRef] [PubMed]

152. Mooranian, A.; Negrulj, R.; Mathavan, S.; Martinez, J.; Sciarretta, J.; Chen-Tan, N.; Mukkur, T.K.; Mikov, M.; Lalic-Popovic, M.; Stojancevic, M.; et al. An advanced microencapsulated system: A platform for optimized oral delivery of antidiabetic drug-bile acid formulations. Pharm. Dev. Technol. 2015, 20, 702-709. [CrossRef] [PubMed] 
153. Mooranian, A.; Negrulj, R.; Arfuso, F.; Al-Salami, H. The effect of a tertiary bile acid, taurocholic acid, on the morphology and physical characteristics of microencapsulated probucol: Potential applications in diabetes: A characterization study. Drug Deliv. Transl. Res. 2015, 5, 511-522. [CrossRef] [PubMed]

154. Mooranian, A.; Negrulj, R.; Al-Sallami, H.S.; Fang, Z.; Mikov, M.; Golocorbin-Kon, S.; Fakhoury, M.; Arfuso, F.; Al-Salami, H. Release and swelling studies of an innovative antidiabetic-bile acid microencapsulated formulation, as a novel targeted therapy for diabetes treatment. J. Microencapsul. 2015, 32, 151-156. [CrossRef]

155. Mooranian, A.; Negrulj, R.; Al-Sallami, H.; Fang, Z.; Mikov, M.; Golocorbin-Kon, S.; Fakhoury, M.; Watts, G.; Matthews, V.; Arfuso, F.; et al. Probucol Release from Novel Multicompartmental Microcapsules for the Oral Targeted Delivery in Type 2 Diabetes. AAPS PharmSciTech 2015, 16, 45-52. [CrossRef]

156. Mooranian, A.; Negrulj, R.; Mathavan, S.; Martinez, J.; Sciarretta, J.; Chen-Tan, N.; Mukkur, T.K.; Mikov, M.; Lalic-Popovic, M.; Stojancevic, M.; et al. Stability and Release Kinetics of an Advanced Gliclazide-Cholic Acid Formulation: The Use of Artificial-Cell Microencapsulation in Slow Release Targeted Oral Delivery of Antidiabetics. J. Pharm. Innov. 2014, 9, 150-157. [CrossRef]

157. Chiang, J.Y.L.; Ferrell, J.M. Bile Acid Biology, Pathophysiology, and Therapeutics. Clin. Liver Dis. 2020, 15, 91-94. [CrossRef] [PubMed]

158. Chiang, J.Y.L.; Ferrell, J.M. Bile Acids as Metabolic Regulators and Nutrient Sensors. Annu. Rev. Nutr. 2019, 39, 175-200. [CrossRef]

159. Lalic-Popovic, M.; Vasovic, V.; Milijasevic, B.; Golocorbin-Kon, S.; Al-Salami, H.; Mikov, M. Deoxycholic Acid as a Modifier of the Permeation of Gliclazide through the Blood Brain Barrier of a Rat. J. Diabetes Res. 2013, 2013, 598603. [CrossRef] [PubMed]

160. Ethanic, M.; Stanimirov, B.; Pavlovic, N.; Vukmirovic, S.; Lazic, J.; Al-Salami, H.; Mikov, M. Transport and Biotransformation of Gliclazide and the Effect of Deoxycholic Acid in a Probiotic Bacteria Model. Front. Pharmacol. 2019, 10, 1083. [CrossRef]

161. Kim, K.; Yoon, I.; Chun, I.; Lee, N.; Kim, T.; Gwak, H.S. Effects of bile salts on the lovastatin pharmacokinetics following oral administration to rats. Drug Deliv. 2011, 18, 79-83. [CrossRef] [PubMed]

162. Gordon, G.S.; Moses, A.C.; Silver, R.D.; Flier, J.S.; Carey, M.C. Nasal absorption of insulin: Enhancement by hydrophobic bile salts. Proc. Natl. Acad. Sci. USA 1985, 82, 7419-7423. [CrossRef]

163. Negrulj, R.; Mooranian, A.; Chen-Tan, N.; Al-Sallami, H.S.; Mikov, M.; Golocorbin-Kon, S.; Fakhoury, M.; Watts, G.F.; Arfuso, F.; Al-Salami, H. Swelling, mechanical strength, and release properties of probucol microcapsules with and without a bile acid, and their potential oral delivery in diabetes. Artif. Cells Nanomed. Biotechnol. 2016, 44, 1290-1297. [CrossRef] [PubMed]

164. Mooranian, A.; Negrulj, R.; Chen-Tan, N.; Watts, G.F.; Arfuso, F.; Al-Salami, H. An optimized probucol microencapsulated formulation integrating a secondary bile acid (deoxycholic acid) as a permeation enhancer. Drug Des. Devel. Ther. 2014, 8 , 1673-1683. [CrossRef]

165. Mooranian, A.; Negrulj, R.; Chen-Tan, N.; Al-Sallami, H.S.; Fang, Z.; Mukkur, T.; Mikov, M.; Golocorbin-Kon, S.; Fakhoury, M.; Arfuso, F.; et al. Novel artificial cell microencapsulation of a complex gliclazide-deoxycholic bile acid formulation: A characterization study. Drug Des. Devel. Ther. 2014, 8, 1003-1012. [CrossRef]

166. Wagle, S.R.; Kovacevic, B.; Walker, D.; Ionescu, C.M.; Shah, U.; Stojanovic, G.; Kojic, S.; Mooranian, A.; Al-Salami, H. Alginatebased drug oral targeting using bio-micro/nano encapsulation technologies. Expert Opin. Drug Deliv. 2020. [CrossRef] [PubMed]

167. Mooranian, A.; Zamani, N.; Kovacevic, B.; Ionescu, C.M.; Luna, G.; Mikov, M.; Goločorbin-Kon, S.; Stojanovic, G.; Kojic, S.; Al-Salami, H. Pharmacological effects of secondary bile acid microparticles in diabetic murine model. Curr. Diabetes Rev. 2020. [CrossRef]

168. Mooranian, A.; Zamani, N.; Takechi, R.; Luna, G.; Mikov, M.; Goločorbin-Kon, S.; Elnashar, M.; Arfuso, F.; Al-Salami, H. An in vivo pharmacological study: Variation in tissue-accumulation for the drug probucol as the result of targeted microtechnology and matrix-acrylic acid optimization and stabilization techniques. PLoS ONE 2019, 14. [CrossRef]

169. Mooranian, A.; Zamani, N.; Mikov, M.; Goločorbin-Kon, S.; Stojanovic, G.; Arfuso, F.; Al-Salami, H. Stability and biological testing of taurine-conjugated bile acid antioxidant microcapsules for diabetes treatment. Ther. Deliv. 2019, 10, 99-106. [CrossRef] [PubMed]

170. Mooranian, A.; Zamani, N.; Takechi, R.; Al-Sallami, H.; Mikov, M.; Goločorbin-Kon, S.; Kovacevic, B.; Arfuso, F.; Al-Salami, H. Pharmacological effects of nanoencapsulation of human-based dosing of probucol on ratio of secondary to primary bile acids in gut, during induction and progression of type 1 diabetes. Artif. Cells Nanomed. Biotechnol 2018, 46, S748-S754. [CrossRef]

171. Mooranian, A.; Takechi, R.; Jamieson, E.; Morahan, G.; Al-Salami, H. The effect of molecular weights of microencapsulating polymers on viability of mouse-cloned pancreatic $\hat{~}^{2}$-cells: Biomaterials, osmotic forces and potential applications in diabetes treatment. Pharm. Dev. Technol. 2018, 23, 145-150. [CrossRef] [PubMed]

172. Mooranian, A.; Negrulj, R.; Takechi, R.; Jamieson, E.; Morahan, G.; Al-Salami, H. Electrokinetic potential-stabilization by bile acidmicroencapsulating formulation of pancreatic $\beta$-cells cultured in high ratio poly-L-ornithine-gel hydrogel colloidal dispersion: Applications in cell-biomaterials, tissue engineering and biotechnological applications. Artif. Cells Nanomed. Biotechnol. 2018, 46, 1156-1162. [CrossRef]

173. Al-Salami, H.; Mamo, J.C.; Mooranian, A.; Negrulj, R.; Lam, V.; Elahy, M.; Takechi, R. Long-Term Supplementation of Microencapsulated ursodeoxycholic Acid Prevents Hypertension in a Mouse Model of Insulin Resistance. Exp. Clin. Endocrinol. Diabetes 2017, 125, 28-32. [CrossRef]

174. Mooranian, A.; Negrulj, R.; Jamieson, E.; Morahan, G.; Al-Salami, H. Biological Assessments of Encapsulated Pancreatic $\beta$-Cells: Their Potential Transplantation in Diabetes. Cell. Mol. Bioeng. 2016, 9, 530-537. [CrossRef] 
175. Mooranian, A.; Negrulj, R.; Chen-Tan, N.; Fakhoury, M.; Arfuso, F.; Jones, F.; Al-Salami, H. Advanced bile acid-based multicompartmental microencapsulated pancreatic beta-cells integrating a polyelectrolyte-bile acid formulation, for diabetes treatment. Artif. CellsNanomed. Biotechnol. 2016, 44, 588-595. [CrossRef]

176. Mooranian, A.; Negrulj, R.; Arfuso, F.; Al-Salami, H. Characterization of a novel bile acid-based delivery platform for microencapsulated pancreatic beta-cells. Artif. Cells Nanomed. Biotechnol. 2016, 44, 194-200. [CrossRef]

177. Mooranian, A.; Negrulj, R.; Al-Salami, H.; Morahan, G.; Jamieson, E. Designing anti-diabetic $\beta$-cells microcapsules using polystyrenic sulfonate, polyallylamine, and a tertiary bile acid: Morphology, bioenergetics, and cytokine analysis. Biotechnol. Prog. 2016, 32, 501-509. [CrossRef]

178. Mooranian, A.; Negrulj, R.; Al-Salami, H. The incorporation of water-soluble gel matrix into bile acid-based microcapsules for the delivery of viable $\beta$-cells of the pancreas, in diabetes treatment: Biocompatibility and functionality studies. Drug Deliv. Transl. Res. 2016, 6, 17-23. [CrossRef]

179. Mooranian, A.; Negrulj, R.; Al-Salami, H. Viability and topographical analysis of microencapsulated $\beta$-cells exposed to a biotransformed tertiary bile acid: An ex vivo study. Int. J. Nano Biomater. 2016, 6, 74-82. [CrossRef]

180. Mooranian, A.; Negrulj, R.; Takechi, R.; Mamo, J.; Al-Sallami, H.; Al-Salami, H. The biological effects of the hypolipidaemic drug probucol microcapsules fed daily for 4 weeks, to an insulin-resistant mouse model: Potential hypoglycaemic and antiinflammatory effects. Drug Deliv. Transl. Res. 2018, 8, 543-551. [CrossRef] [PubMed]

181. Faustino, C.; Serafim, C.; Rijo, P.; Reis, C.P. Bile acids and bile acid derivatives: Use in drug delivery systems and as therapeutic agents. Expert Opin. Drug Deliv. 2016, 13, 1133-1148. [CrossRef] [PubMed]

182. Pang, J.; Xiong, H.; Lin, P.; Lai, L.; Yang, H.; Liu, Y.; Huang, Q.; Chen, S.; Ye, Y.; Sun, Y.; et al. Activation of miR-34a impairs autophagic flux and promotes cochlear cell death via repressing ATG9A: Implications for age-related hearing loss. Cell Death Dis. 2017, 8, e3079. [CrossRef] [PubMed]

183. Mooranian, A.; Zamani, N.; Ionescu, C.M.; Takechi, R.; Luna, G.; Mikov, M.; Golocorbin-Kon, S.; Kovacevic, B.; Al-Salami, H. Oral gavage of nano-encapsulated conjugated acrylic acid-bile acid formulation in type 1 diabetes altered pharmacological profile of bile acids, and improved glycaemia and suppressed inflammation. Pharmacol. Rep. 2020, 72, 368-378. [CrossRef] [PubMed]

184. Gvoic, M.; Vukmirovic, S.; Al-Salami, H.; Mooranian, A.; Mikov, M.; Stankov, K. Bile acids as novel enhancers of CNS targeting antitumor drugs: A comprehensive review. Pharm. Dev. Technol. 2021, 1-17. [CrossRef]

185. Mathavan, S.; Ionescu, C.M.; Kovacevic, B.; Mikov, M.; Golocorbin-Kon, S.; Mooranian, A.; Dass, C.R.; Al-Salami, H. Histological effects of pharmacologically active human bile acid nano/micro-particles in Type-1 diabetes. Ther. Deliv. 2020, 11, 157-171. [CrossRef]

186. Maksimovic, V.; Pavlovic-Popovic, Z.; Vukmirovic, S.; Cvejic, J.; Mooranian, A.; Al-Salami, H.; Mikov, M.; Golocorbin-Kon, S. Molecular mechanism of action and pharmacokinetic properties of methotrexate. Mol. Biol. Rep. 2020, 47, 4699-4708. [CrossRef] [PubMed]

187. Kecman, S.; Škrbić, R.; Badnjevic Cengic, A.; Mooranian, A.; Al-Salami, H.; Mikov, M.; Golocorbin-Kon, S. Potentials of human bile acids and their salts in pharmaceutical nano delivery and formulations adjuvants. Technol. Health Care 2020, $28,325-335$. [CrossRef]

188. Jovic, J.; Milijasevic, B.; Vukmirovic, S.; Vasovic, V.; Mikov, M.; Mooranian, A.; Al-Salami, H.; Golocorbin-Kon, S. Pharmacokinetic and Drug Absorption Profiles of the Anti-Hyperglycaemic Agent Gliclazide in Oral Tissue-Targeted Microcapsules in Rats. Scr. Med. 2020, 51, 15-20. [CrossRef]

189. Zangerolamo, L.; Vettorazzi, J.F.; Rosa, L.R.O.; Carneiro, E.M.; Barbosa, H.C.L. The bile acid TUDCA and neurodegenerative disorders: An overview. Life Sci. 2021, 272, 119252. [CrossRef] [PubMed]

190. Hu, J.; Xu, M.; Yuan, J.; Li, B.; Entenman, S.; Yu, H.; Zheng, Q.Y. Tauroursodeoxycholic acid prevents hearing loss and hair cell death in Cdh23(erl/erl) mice. Neuroscience 2016, 316, 311-320. [CrossRef]

191. Berger, E.; Haller, D. Structure-function analysis of the tertiary bile acid TUDCA for the resolution of endoplasmic reticulum stress in intestinal epithelial cells. Biochem. Biophys. Res. Commun. 2011, 409, 610-615. [CrossRef]

192. Balandraud-Pieri, N.; Queneau, P.E.; Caroli-Bosc, F.X.; Bertault-Peres, P.; Montet, A.M.; Durand, A.; Montet, J.C. Effects of tauroursodeoxycholate solutions on cyclosporin A bioavailability in rats. Drug Metab. Dispos. 1997, 25, 912-916. [PubMed]

193. Yao, B.; He, J.; Yin, X.; Shi, Y.; Wan, J.; Tian, Z. The protective effect of lithocholic acid on the intestinal epithelial barrier is mediated by the vitamin D receptor via a SIRT1/Nrf2 and NF-kappaB dependent mechanism in Caco-2 cells. Toxicol. Lett. 2019, 316, 109-118. [CrossRef] [PubMed]

194. Buki, B.; Junger, H.; Zhang, Y.; Lundberg, Y.W. The Price of Immune Responses and the Role of Vitamin D in the Inner Ear. Otol. Neurotol. 2019, 40, 701-709. [CrossRef] [PubMed]

195. Zou, J.; Minasyan, A.; Keisala, T.; Zhang, Y.; Wang, J.H.; Lou, Y.R.; Kalueff, A.; Pyykko, I.; Tuohimaa, P. Progressive hearing loss in mice with a mutated vitamin D receptor gene. Audiol. Neurootol. 2008, 13, 219-230. [CrossRef] [PubMed] 